\title{
Orhan Kemal'in Bereketli Topraklar Üzerinde ve Gurbet Kuşları Romanlarının Edebiyat Coğrafyası Açısından İncelenmesi
}

\author{
Analysis of Orhan Kemal's Novels Bereketli Topraklar Üzerinde and Gurbet Kuşları From \\ Literary Geography Perspective
}

\author{
Uğurcan AYİK ${ }^{1} \oplus$, İsmail İLİ ${ }^{2}$ (
}

${ }^{1}$ Dr. Öğr. Üyesi, Gaziantep Üniversitesi, Fen Edebiyat Fakültesi, Coğrafya Bölümü, Gaziantep, Türkiye

${ }^{2}$ Lisans Öğrencisi, Gaziantep Üniversitesi, Fen Edebiyat Fakültesi, Coğrafya Bölümü, Gaziantep, Türkiye

ORCID: U.A. 0000-0003-2019-5151; İ.İ. 0000-0001-8808-7814

\section{öz}

Edebiyat Coğrafyası ülkemizde Coğrafya'nın yeni gelişen alt araştırma alanlarından biri olma özelliğini taşımaktadır. Edebiyat Coğrafyası araştırmalarında; coğrafi görünümün aktarılması, fiziki ve beşeri coğrafya elemanlarının edebi eserlerdeki kullanımı ve yazarın hayat deneyimi gibi birçok başı̧ı önem taşır. Bu çalışma Orhan Kemal'in "Bereketli Topraklar Üzerinde" ve "Gurbet Kuşları" romanlarının Edebiyat Coğrafyası kapsamında, oluşturulan şehirsel coğrafi kodlar üzerinden araştırımasına dayanmaktadır. Bu romanlardaki şehirsel coğrafi unsurların belirlenmesi ve bunların romanlardaki kullanımının açıklanması ise çalışmanın ana amacını oluşturmaktadır. Çalışmada nitel araştırma yöntemlerinden biri olan doküman incelemesi yöntem olarak kullanılmıştır. İlgili romanlar içerik analizine tabi tutulmuş, önceden oluşturulmuş kavramlarla ilgili kodlar MAXQDA 2020 programı vasıtasıyla analiz edilmiştir. "Gurbet Kuşları" romanında geçen semtlerin ve mekânların haritalandırılmasında ise ArcGIS 10.3 ve CorelDraw X5 programlarından faydalanılmıştır. Çalışma kapsamında Orhan Kemal'in her iki romanında da olayların geçtiği İstanbul ve Adana şehirlerinin yazıldıkları dönemlere özgü şehirsel coğrafi yapılarının romanlara somut bir şekilde yansıdığı tespit edilmiştir. Bu çalışma gerek edebiyat ve şehir arasındaki ilişkiyi göstermesi, gerekse de Edebiyat Coğrafyası çalışmalarına katkı sunması açısından önem arz etmektedir. Bu açıdan bu araştırmanın var olan literatürde önemli bir boşluğu dolduracağı düşünülmektedir. Dolayısıyla ileride Edebiyat Coğrafyası alanında yapılacak olan birçok çalışmaya da yol gösterici olacaktır.

Anahtar kelimeler: Edebiyat Coğrafyası, Orhan Kemal, Nitel Araştırma

\section{ABSTRACT}

Literary Geography is one of the newly-emerging sub-research areas of Geography in Turkey. Literary geography studies discuss topics such as transferring the geographical view, the use of physical and human geography elements in literary works, and the author's experiences. This study analyzes Orhan Kemal's novels Bereketli Topraklar Üzerinde and Gurbet Kuşları considering predetermined urban geographical codes within the scope of literary geography. It aims at spotting the urban geographical elements and explaining their use in the novels. A qualitative research method was used, more specifically, that of document analysis. Both novels were subjected to content analysis, and codes related to the predetermined concepts were analyzed through MAXQDA 2020. ArcGIS 10.3 and CorelDraw X5 programs were used in mapping the districts and places in the Gurbet Kuşları novel. The results of the study show that the period-specific urban geographical structures of Istanbul and Adana, which were the cities home to the plots of both novels, were concretely visible in the two works. This study is significant as it reveals the relationship between literature and the city and contributes to studies of literary geography. In this respect, the present research will fill a considerable gap in the existing literature. Therefore, it will guide many other studies to be conducted in the field of literary geography in the future.

Keywords: Literary Geography, Orhan Kemal, Qualitative Research

Başvuru/Submitted: 17.02.2020 • Revizyon Talebi/Revision Requested: 21.05.2020 • Son Revizyon/Last Revision Received: 23.05 .2020 - Kabul/Accepted: 04.06.2020 - Online Yayın/Published Online: 24.06 .2020 


\section{EXTENDED ABSTRACT}

In this study, Orhan Kemal's novels Bereketli Topraklar Üzerinde and Gurbet Kusları were discussed in the context of literary geography. Several codes were determined for both novels within the scope of urban geographical elements. These codes are rural-tourban migration, urban construction and development, urban functions, squatting and urban geographical view. Furthermore, urban functions were divided into sub-categories, namely industrial function, transportation function, trade function, agriculture function and housing function. Also, the frequency of certain words was checked throughout the novel since they represent Turkish urbanization between the years 1950 and 1980. These words were gurbet (abroad), göç (migration), traktör (tractor), Çukurova, gecekondu (squatter), fabrika (factory), Istanbul and şehir (city). The books were analyzed with MAXQDA 2020, ArcGIS 10.3 and CorelDraw X5. Single-Case Model, Two-Case Model and pie charts were created through MAXQDA 2020, while ArcGIS 10.3 and Corel Draw X5 programs were used in spatial mapping. The analyses in this study showed that urban geographical elements were widely used in both of the novels examined here. The industrial function was coded 21 times throughout Bereketli Topraklar Üzerinde. Agriculture-based industry, which takes place due to cotton production in Çukurova, was highlighted with this code. In the numerical distribution of the relevant codes, rural-to-urban migration was seen to be the second most prominent code with a frequency of 16. The emphasis on Central Anatolia implies the tendency of immigration to nearby centers in the first place. The transportation function constitutes the third most frequent coding. The emphasis on inner-city transportation is remarkable in this coding. The chapter with the greatest occurrence of the agriculture function is the last chapter where the protagonists work as laborers across Çukurova at the end of the book. The agriculture function was coded 4 times throughout the book as was the urban geographical view. Lastly, the housing function was coded twice and the trade function once. Based on the selected words, the most frequent words in Bereketli Topraklar Üzerinde were analyzed. It was found that şehir occurred 116 times, fabrika 104, Çukurova 57, traktör 21, gurbet 35, göç 3 times, and Istanbul 1 time, but gecekondu was not used at all. Regarding proportional distribution of the word frequencies, şehir has a share of $35 \%$, fabrika has $31 \%$, Çukurova $17 \%$, gurbet $10 \%$, traktör $6 \%$, göç 1\%, İstanbul $0,3 \%$, and gecekondu $0 \%$.

In the other novel, Gurbet Kuşları, rural-to-urban migration was coded 19 times, the highest frequency. The author describes migration by supporting it with many constituents such as countrymen relations in the city, and places receiving and sending migrating populations. Throughout the book, "gecekondulaşma" was coded 13 times. Zeytinburnu is the place where the phenomenon of squatting is found in the book. Urban construction movements were coded 13 times. In Gurbet Kuslarl, the transportation function was coded 11 times. The author conveyed many vehicles of highway, seaway and railway transport to the reader, along with their functionality in the city. The industrial function was coded 8 times. Urban geographical view and trade function were coded 4 times each. The author's narrations in various sections of Gurbet Kuşlarl concerning the urban geographical view describe street, road, and neighborhood views of Istanbul, and the selected words have the following frequencies: Istanbul 170, Çukurova 61, gurbet 57, şehir 55, gecekondu 28, fabrika 28, göç 1, traktör 0 . As for percentages; Istanbul $43 \%$, Çukurova $15 \%$, şehir 14\%, gurbet $13 \%$, fabrika and gecekondu $7 \%$, göç $0,25 \%$, and traktör $0 \%$.

The two-case model allows results to be reached by comparing two cases. The two novels show similar and different urban geographical elements in the codings. The similarities are the codes of rural-to-urban migration, industrial function, transportation function, urban geographical view and trade function. However, narrations of agriculture and housing functions are covered only in Bereketli Topraklar Üzerinde. Squatting and urban construction and development appear only in Gurbet Kuşları. A striking detail here is the implication of developmental differences between Istanbul and Adana in the novels. Intra-urban squatting movements became evident first in Istanbul, Ankara and Izmir and then all over Turkey. Therefore, squatting and urban construction and development are specific to Gurbet Kuşlarl, which focuses on Istanbul as the space. In contrast, Bereketli Topraklar Üzerinde focuses on Adana (Çukurova). Reference to agricultural function in this book presents a situation compliant with the overall quality of the novel.

In this study, the novels Bereketli Topraklar Üzerinde and Gurbet Kuşları were analyzed with codes created in the light of certain urban geographical elements. The author's close contact with people made human geographical elements and their spatial reflections dominant in his novels. Yet, narration of physical geographical elements is clearly weak in his works. On the other hand, urban functions like transportation, industry, housing, trade, squatting, construction movements in 1950s' Istanbul, and urban geographical views are found to be the most manifest geographical elements in the author's narration. Moreover, the use of places and spaces in the novels studied here witnesses the evolutionary process of the settlements. 


\section{GİRIŞ}

Coğrafya'nın genel kabul gören terimsel karşılığında geo'nun “yer" graphein'in "tasvir" olduğu ve yeryüzünün görünen, bilinen ve keşfedilen özelliklerinin betimsel olarak aktarımı anlamına geldiği bilinmektedir (Doğanay, 1999, s. 32; Özçağlar, 2010, s. 2). Özellikle 20.yüzyılın ortalarındaki kantitatif devrime kadar Coğrafya'nın tasvir etme geleneği baskın karakterini korumuştur. $\mathrm{Bu}$ tarz Coğrafya yapma geleneğinde bir bölgenin fiziki ve beşeri özellikleri ile aktarımı önem taşımaktadır. $\mathrm{Bu}$ açıdan bakıldığında Coğrafya'nın her ne kadar günümüzde tasvir boyutunun iyice azalmış olduğu gerçeği göz önünde tutulursa da tamamen bilim dışında kaldığını söylemek mümkün değildir. Hatta Edebiyat ve Coğrafya ilişkisinde yazarların çoğu zaman başvurdukları doğa tasvirleri içinde coğrafyacıların ilgi alanına giren Fiziki Coğrafya'ya ait birçok unsurun da izlerini görmek mümkündür. Buna karşıllık birçok eserdeki şehir, nüfus, ulaşım ile ilgili anlatımlar da Coğrafya'nın beşeri kolunun inceleme alanına girmektedir. Bu karşılıklı etkileşim, kökleri her ne kadar eski olsa da ağırlıkla yakın dönemde şekillenmiş olan Edebiyat Coğrafyası çalışmalarının ana hattını özetlemektedir.

$\mathrm{Bu}$ çalışmada Edebiyat Coğrafyası kapsamında Orhan Kemal'in "Bereketli Topraklar Üzerinde" ve "Gurbet Kuşları" romanları şehirsel coğrafi unsurlar kapsamında oluşturulmuş birtakım kodlarla incelenmiştir. Kodların şehirsel coğrafi unsurlarla sınırlı tutulmasının birinci nedeni yazarın mekân seçiminde şehri sıklıkla tercih etmesinden kaynaklanmaktadır. İkinci neden ise her iki eserde de Fiziki Coğrafya anlatımının yok denecek kadar az olmasıdır. $\mathrm{Bu}$ nedenle her iki roman için oluşturulan şehirsel coğrafi kodlar Beşeri Coğrafya kapsamında ele alınmıştır. Bu iki roman aynı zamanda çalışmanın kapsamını da oluşturmaktadır. Orhan Kemal'in bu çalışmaya konu olan iki eserinin seçilmesinin bazı nedenleri bulunmaktadır. Öncelikle Orhan Kemal'in romanları mekânsal açıdan İstanbul'da ve Adana'da geçen romanlar olarak ikili yapıda sınıflandırılabilir. "Bereketli Topraklar Üzerinde" ve "Gurbet Kuşları" adlı eserler yazarın seri romanları olmalarının yanında birisinin Adana'da, diğerinin ise İstanbul'da geçmesi yazarın mekânsal kurgusunun anlaşılması açısından iyi bir kategorik ayrım sunmaktadır. Buna ek olarak Orhan Kemal, toplumcu gerçekçi edebiyat anlayışının temsilcisi olarak toplumu ve yaşadığı coğrafyayı somut gerçeklikleri üzerinden anlatan bir yazardır. Yazarın anlatımlarında şehrin baskınlığı dikkat çeker. Bu çalışmaya konu olan her iki romanında da şehirsel mekânın anlatımı ön plandadır. Fakat "Bereketli Topraklar Üzerinde" romanı Çukurova'daki kırsal hayatı da yansıtmaktadır.

Orhan Kemal'in her iki romanındaki şehirsel coğrafi unsurların aktarılması ve bunların açıklanması çalışmanın ana amacını oluşturmaktadır. Orhan Kemal, 1950-1980 arası dönemi, bir başka deyişle Türkiye'deki şehirleşme hareketlerinin önceki dönemlere göre çok hızlı olduğu bir dönemi, gerçekleşen mekânsal ve toplumsal değişikliklerle beraber eserlerine aktarmıştır. "Bereketli Topraklar Üzerinde" ve "Gurbet Kuşları" romanları da kırsal ve şehirsel alandaki bu değişiklikleri somut gerçeklikler üzerinden anlatmaktadır. Bu anlatım aynı zamanda çalışmanın önemini de ortaya koymaktadır. Hem coğrafyacılar hem de diğer disiplinlere mensup araştırmacilar tarafindan bu değişim çoğu zaman akademik çalışmalarda işlenmiş ve işlenmeye devam edilmektedir. Fakat Edebiyat ve Coğrafya ilişkisi açısından Orhan Kemal'in eserleri Coğrafya disiplini altında şimdiye kadar incelenmemiştir. Özellikle Batı'da Edebiyat Coğrafyası çalışmalarında yazarların eserleri çok daha önce incelenmeye başlanmıştır. Türkiye'de ise bu yönelim oldukça yenidir. Bu durum Türkiye'deki Coğrafya çalışmaları için multidisipliner ilişkinin sağlanması açısından sorun oluşturmaktadır. Dolayısıyla böyle bir incelemenin yapılması ileride Edebiyat Coğrafyası alanında yapılacak çalışmalara önemli bir altlık oluşturacağı gibi, literatürde de önemli bir boşluğu doldurmaya adaydır. Ayrıca Edebiyat Coğrafyası alanında hem dünyada hem de ülkemizde yöntem açısından ortaklaşma söz konusu değildir. Bu çalışma nitel yaklaşımla edebi eserlerin nasıl ele alınabileceğini de somutlaştırmaktadır. Bu durum aynı zamanda çalışmaya ikinci bir özgünlük alanı yaratmaktadır.

\section{AMAÇ VE YÖNTEM}

Orhan Kemal'in 1950-1970 yılları arasında yoğunlaşan edebi eserlerinde mekânsal açıdan İstanbul ve Adana'nın anlatımı ön plandadır. $\mathrm{Bu}$ iki şehrin anlatımı yazarın hayat tecrübesiyle yakından ilişkilidir. Bu incelemede her iki eserdeki şehirsel coğrafi unsurların araştırılması çalışmanın ana amacını oluşturmaktadır.

Çalışmada nitel araştırma yöntemlerinden olan doküman incelemesi yöntem olarak seçilmiştir. Doküman incelemesi araştırılan konudaki olgu ve/veya olgular hakkında bilgi içeren yazılı materyallerin analizini kapsar. Doküman incelemesi tek başına veri toplama aracı olarak kullanılabileceği gibi, diğer veri toplama yöntemleriyle beraber de kullanılabilir (Yıldırım ve Şimşek, 2016, s. 189). Bu çalı̧̧madaki temel dokümanlar "Bereketli Topraklar Üzerinde" ve "Gurbet Kuşları" romanlarıdır. İlgili romanlar içerik analizine tabi tutularak oluşturulan çeşitli kodlarla mikro düzeyde incelenmeye hazır hale getirilmiştir. İçerik analizine dair Strauss ve Corbin'in çalışmasında (1990) üç farklı kodlama biçimi tanımlanmıştır. Bunlardan birincisi "daha önceden belirlenmiş kavramlara göre yapılan kodlama", ikincisi "verilerden çıkarılan kavramlara göre yapılan kodlama", 


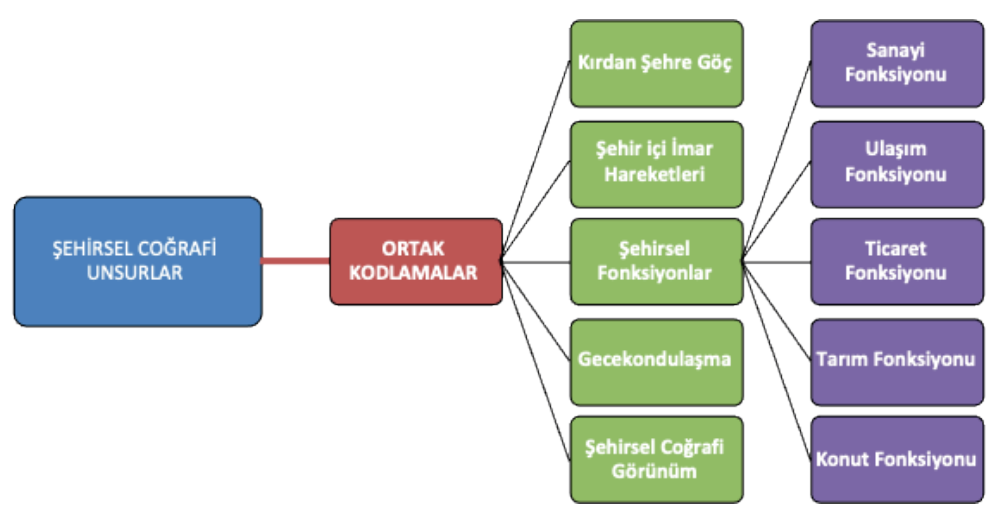

Şekil 1: Her iki eser için oluşturulmuş ortak kodlamalar.

Figure 1: Common codings created for both works.

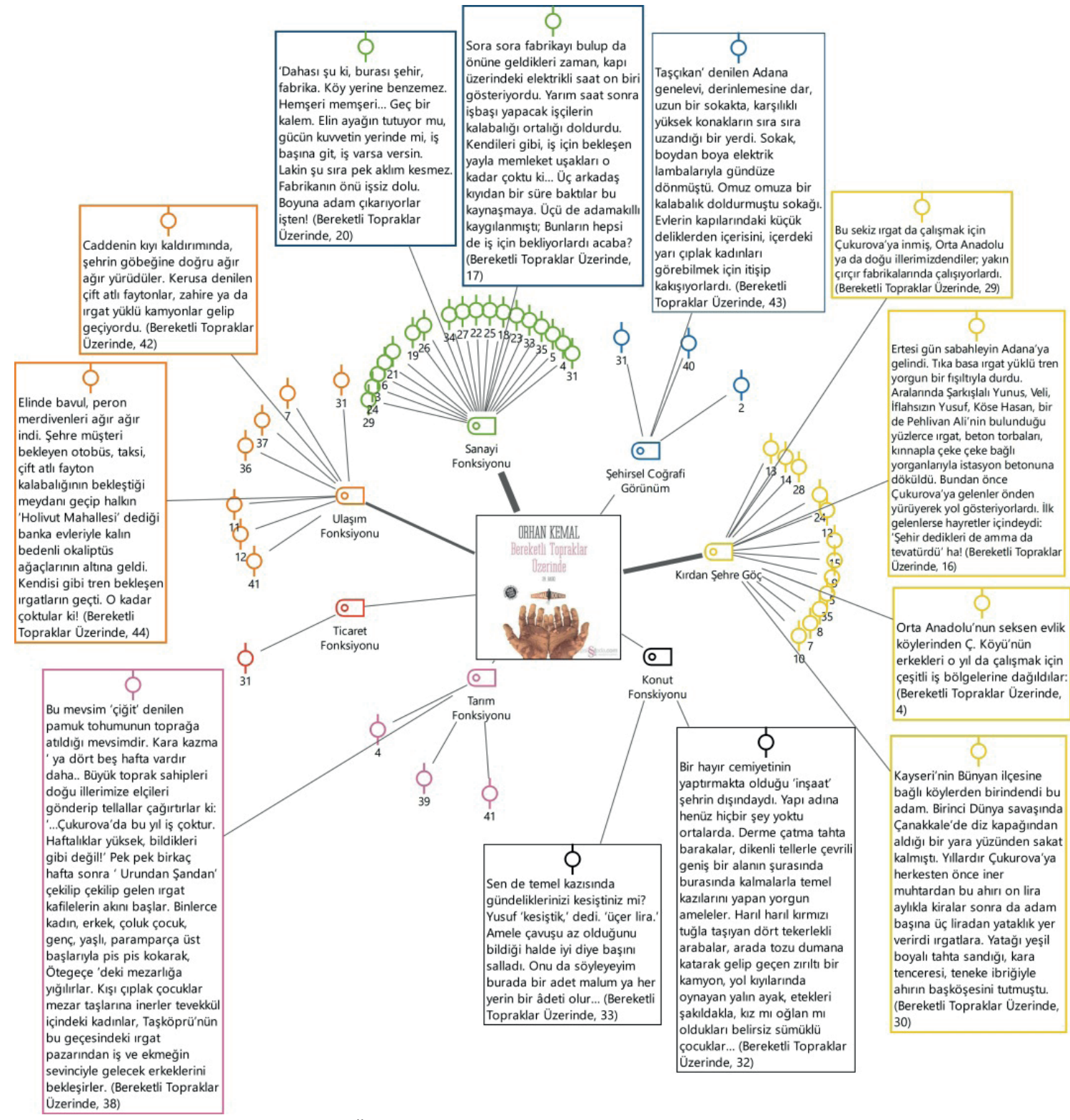

Şekil 2: Illgili kod başıklarına göre Bereketli Topraklar Üzerinde romanında oluşan Tek-Vaka Modeli. Çizgi kalınlıkları kodlanma sıklığını göstermektedir. Figure 2: Single-Case Model, which is formed in the novel Bereketli Topraklar Üzerinde according to the related code titles. Line thicknesses show the frequency of coding. 
"üçüncüsü ise "genel bir çerçeve içinde yapılan kodlama"dır (Strauss ve Corbin 1990'a atfen; Yıldırım ve Şimşek, 2016, s. 244). Bu çalışmada daha önceden belirlenmiş kavramlara göre yapılan kodlama türü tercih edilmiştir. İlgili kodlar üst başlıkta kavramsal olarak şehirsel coğrafi unsurlar olarak ele alınmıştır.
Buna ek olarak Orhan Kemal'in şehirle olan bağındaki beşer vurgusu da göz önünde bulundurulmuştur. İlgili romanlar ilk etapta ön okuma süreçlerine tabi tutulmuştur. Daha sonra detaylı okuma sürecine girilmiş, daha önceden belirlenen kodlarla kodlamalar gerçekleştirilmiştir (Şekil 1).

\begin{tabular}{|c|c|c|}
\hline Kod Sistemi & Bereketli Topraklar Üzerinde & Gurbet Kuşları \\
\hline$\odot$ Gurbet & - $\Rightarrow 35$ & $\bullet \Rightarrow 57$ \\
\hline ๑Gös & $\Rightarrow 3$ & $\Rightarrow 1$ \\
\hline$\odot$ Traktör & $\cdot \Rightarrow 21$ & \\
\hline$\odot_{\bullet}$ çukurova & - $\Rightarrow 57$ & $\Rightarrow 61$ \\
\hline ๑G Gecekondu & & $\cdot \Rightarrow 28$ \\
\hline$\odot$ Fabrika & $\Rightarrow 104$ & $\cdot \Rightarrow 28$ \\
\hline$\odot$ İstanbul & $\Rightarrow 1$ & $\Rightarrow 170$ \\
\hline$\sigma_{\text {Şsehir }}$ & $\Rightarrow 116$ & - $\Rightarrow 55$ \\
\hline
\end{tabular}

Şekil 3: Seçilmiş kelimelere göre romanlardaki kelimelerin kullanım sıklıkları.

Figure 3: Frequency of use of words in novels according to the selected words.

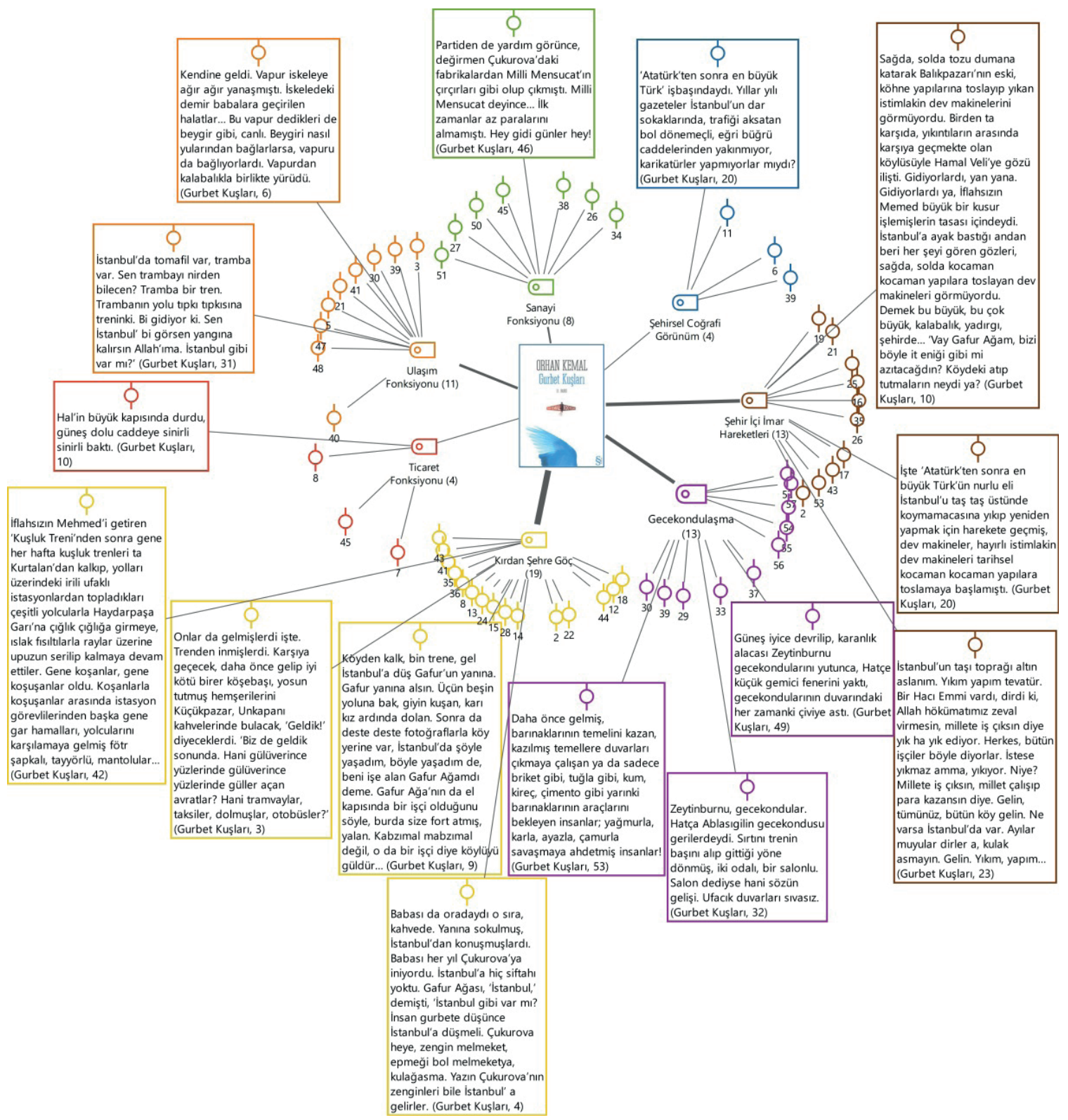

Şekil 4: Illgili kod başlıklarına göre Gurbet Kuşları romanında oluşan Tek-Vaka Modeli. Çizgi kalınlıkları kodlanma sıklığını göstermektedir. Figure 4: Single-Case Model, which is formed in the novel Gurbet Kuşları according to the related code titles. Line thicknesses show the frequency of coding. 
Romanların analizinde MAXQDA 2020, ArcGIS 10.3 ve CorelDraw X5 programlarından yararlanılmış ve analizler gerçekleştirilmiştir. Bu analizler aşağıdaki gibidir:

2.1.Tek Vaka Modeli: $\mathrm{Bu}$ model, incelenen unsura ait yapılan kodlamalara bağlı olarak MAXQDA 2020 programında bir kod yapılanması veya şeması oluşturulmasını sağlamaktadır. Bu çalışmada her iki roman için oluşturulmuş ortak kodlara bağ $l_{1}$ olarak ayrı ayrı kodlamalar gerçekleştirilmiştir. Sonuçta her iki romana ait kod dağılışları ayrı ayrı şematize edilip, çalışmada kullanılmıştır (Şekil 2 ve Şekil 4).

2.2.İki Vaka Modeli: Bu model incelenen iki ayrı unsura ait yapılan kodlamalara bağlı olarak MAXQDA 2020 programında bir kod yapılanması veya şema oluşturulmasını sağlamaktadır. Çalışmada her iki romana ait ortak kodlamalar neticesinde, hangi kodun hangi kitapta ortaklaştığı veya farklılaştığı analiz edilmiştir (Şekil 5).
2.3.Kelime frekanslarının dağılımı: Çalışmada şehirsel coğrafi unsurlarla bağlantılı sekiz adet kelime belirlenmiştir. Bunlar şehir, İstanbul, fabrika, Çukurova, gurbet, gecekondu, traktör ve göçtür. İlgili kelimelerin geçiş sıklıkları sayısal olarak ifade edilmiştir (Şekil 6).

2.4.Mekânsal haritalama: Edebiyat Coğrafyası çalışmalarında kartografik gösterimler yapılan bazı çalışmalarda tercih edilmektedir. Çalışmada "Gurbet Kuşları" romanında yazarın vurguladığı İstanbul'daki semtler ve mekânlar ArcGIS 10.3 ve CorelDraw X5 programları vasıtasıyla haritalandırılmıştır (Şekil 7).

\section{LITERATÜR ÖZETİ}

Edebiyat Coğrafyası veya edebi metinlerde coğrafi ögelerin karşılıklarını aramak her ne kadar çıkış noktası olarak eski olsa da, yöntem ve yönelim açısından yenidir. Özellikle edebi eserleri

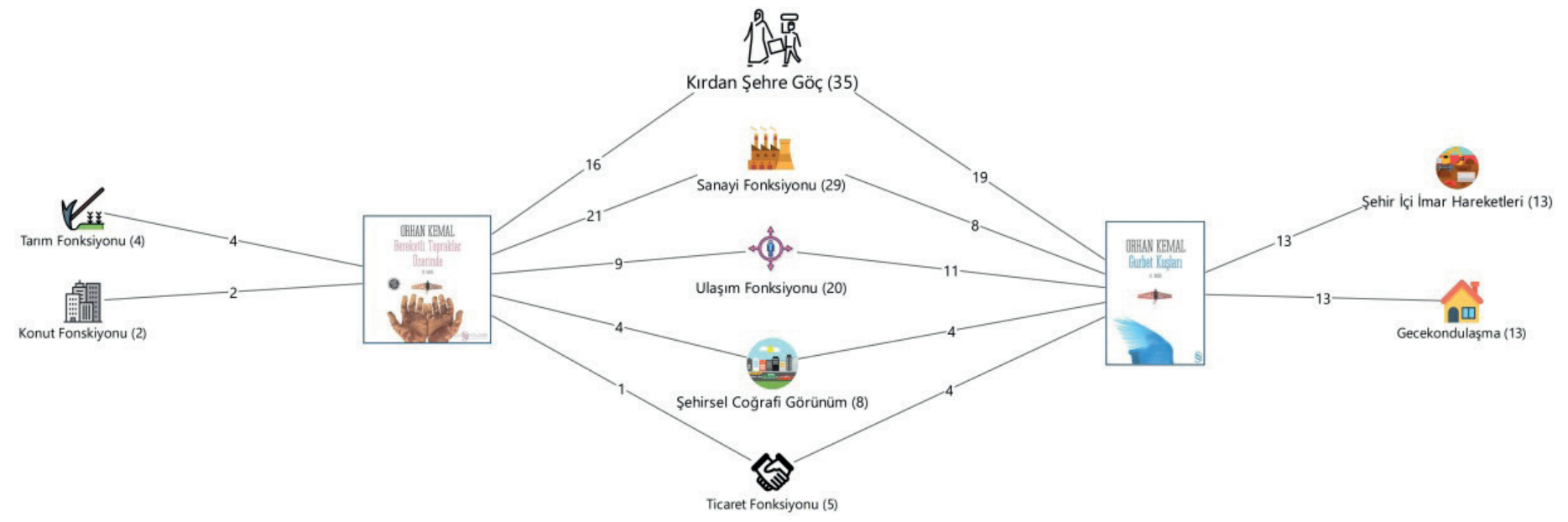

Şekil 5: Her iki romana göre oluşan iki vaka modeli.

Figure 5: Two-case models based on both novels.

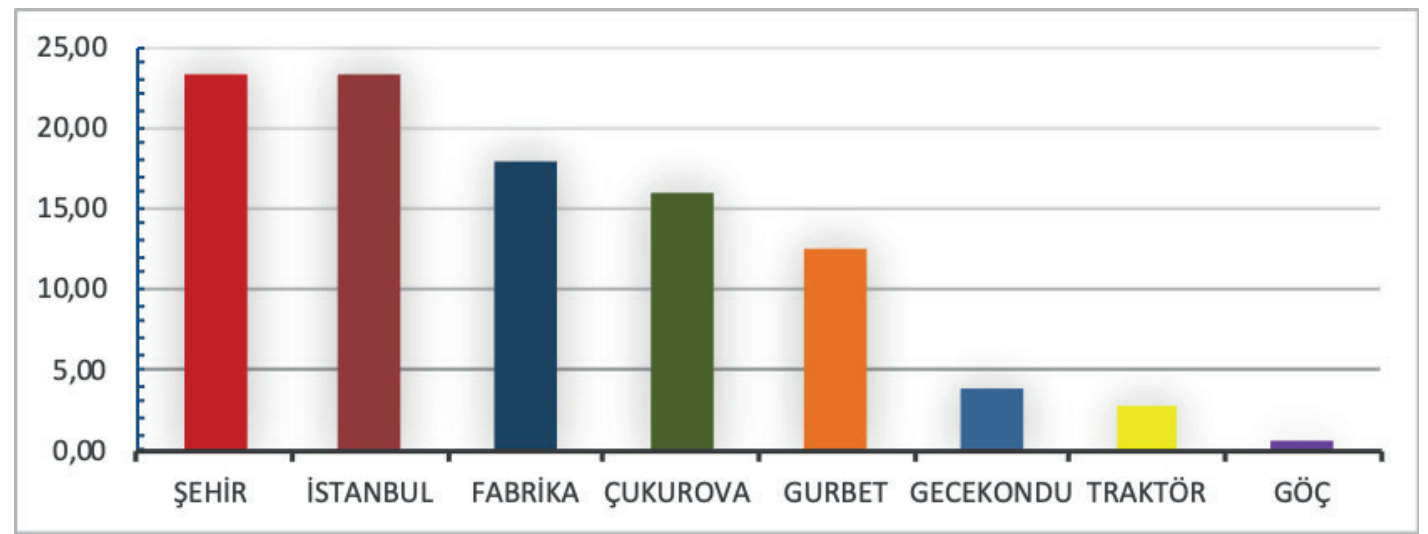

Şekil 6: Seçilmiş kelimelere göre her iki romandaki kelimelerin oransal dağılımı (\%).

Figure 6: Proportional distribution of words in both novels according to the selected words (\%). 


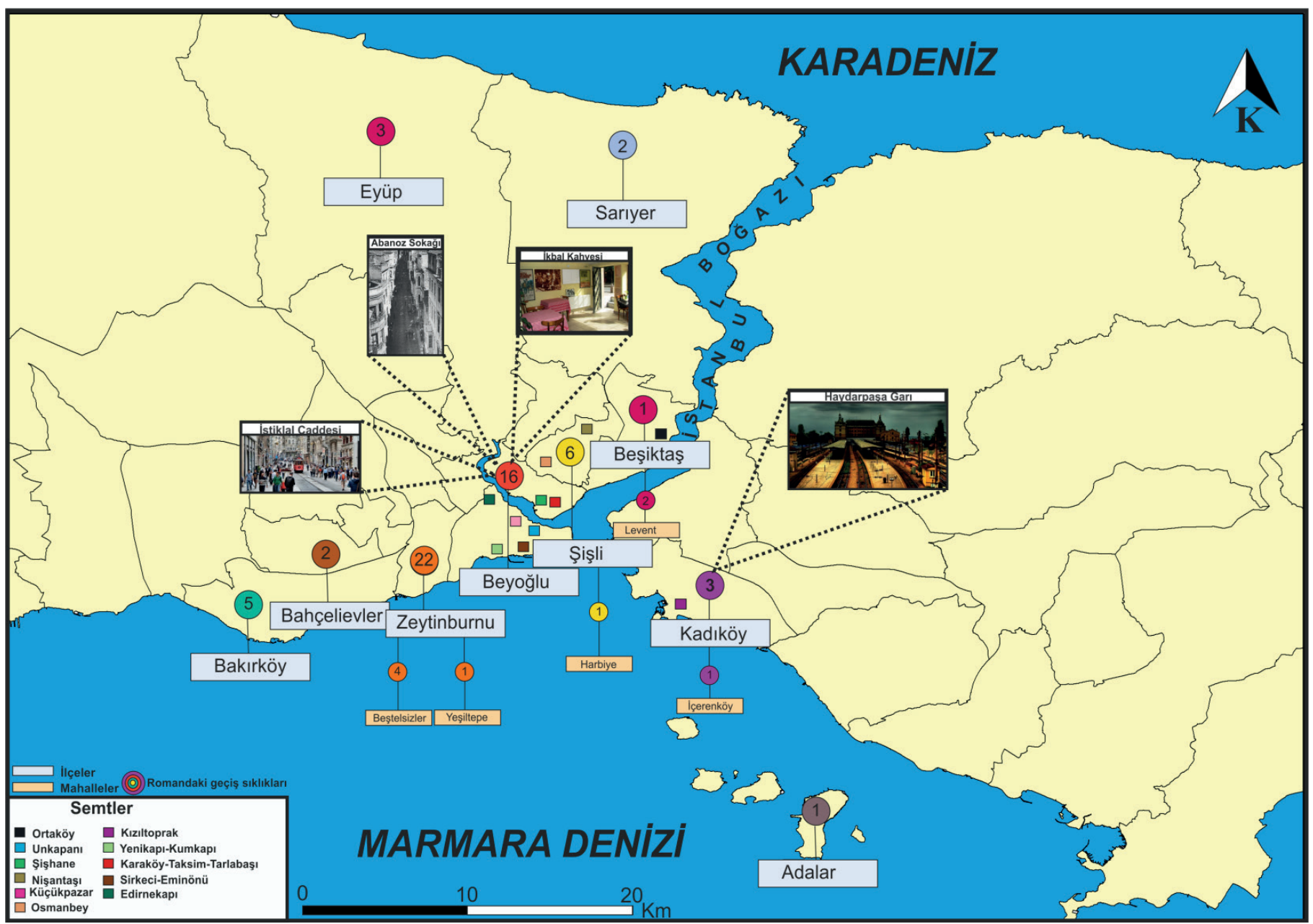

Şekil 7: Gurbet Kuşları romanında anlatımın geçtiği İstanbul'daki semtler ve mekânlar.

Figure 7: The places and district in Istanbul where the story takes place in the novel Gurbet Kuşları.

yazanların mekânı kullanmaları ve Coğrafya'yı çok daha geniş kitlelere ulaştırabilme potansiyelleri Edebiyat Coğrafyası çalışmalarına önem atfetmektedir. Doğanay (1999)'da nerede Coğrafya vardır sorusu üzerinden fen bilimleri, sosyal bilimler, edebiyat ve sanatta Coğrafya'nın olabileceğini tartışmaktadır. Aynı yazar görüşünü ise Manas Destanı, Dede(m) Korkut, OrhunYenisey Anıtları, Divan-1 Lügat-i Türk gibi eserleri göstererek desteklemektedir. Hatta yakın zamanda Manas Destanı veya Dede(m) Korkut kitabında geçen coğrafi yer adları, Türk halk şiiri veya Divan Edebiyatı'nda Coğrafya, Türk romanında Coğrafya, sanat ve coğrafi çevrenin ilişkisi gibi birçok konuda yazara göre çalışmalar olacaktır (Doğanay, 1999, s. 14-16).

İlk baskısı 1967 yılında yapılan Nesillerin Ruhu adlı eserinde Kaplan, Edebiyat Coğrafyası'na ufak ama neredeyse Türkiye'de ilk kez yer ayırmıştır. Çevreci deterministik bir anlayışın yansıması olarak görülebilecek çalışmada coğrafyanın insanları, toplumları ve doğal olarak edebiyatı da etkilediğinden bahsedilmiştir (Kaplan, 1978, s. 85-88). Türkçe'de Edebiyat ve Coğrafya ilişkisine dair ilk derli toplu literatür değerlendirmesine ise Tümertekin ve Özgüç (2002)'de rastlamak mümkündür. Burada yazarlar İngiliz coğrafyacı H.R. Mill'in 1910 y1lında belirttiği tarihi roman gibi coğrafi roman geliştirmenin de önemli olduğu tezini Edebiyat ve Coğrafya ilişkisinin tarihselliğini göstermekte kullanmışlardır (Tümertekin ve Özgüç, 2002, s. 94). Fakat burada atlanılan ve çok daha öncelere konumlanan çalışmalardan biri Wright'ın 1924 yılında yazdığı ufak bir değerlendirme yazısıdır. Burada Wright 1920'li yılların atmosferinde coğrafyacıların edebiyattaki coğrafi vurgulara olan ilgisizliğinden yakınmakta, Hugh Robert Mill'in 1910 yılında yazdığı çalışması olan "Guide to Geographical Books and Appliances" adlı eserine ve 1920 yılında Wharton tarafindan editörlüğü yapılan "Short List of Novels and Literary Works of Geographic Interests" adlı çalışmasına atıf yapmaktadır. Ayrıca bu iki eser dışında o yıllarda literatürle ilgili çalışmalara da değinilmektedir (Wright, 1924). 
Tümertekin ve Özgüç (2002)'de yazarlar 1950'li yıllara kadar Edebiyat ve Coğrafya ilişkisini vurgulayan birtakım eserlerin üretildiğinden bahsetmektedir (Wright ve Platt, 1947; Darby, 1948). Fakat özellikle 1950'li yıllardan sonra bilimde gerçekleşen kantitatif devrimin etkisi nesnel, objektif olanı ön plana almış, bunun neticesinde Edebiyat Coğrafyası inceleme alanı olarak öznel bulunmuş ve bu durum çalışma alanının bilim dışı, kişisel ve subjektif olarak değerlendirilmesini de beraberinde getirmiştir (Tümertekin ve Özgüç, 2002, s. 94). Edebiyat Coğrafyası'nın gelişim seyrinin ise 1970'li yıllarla beraber arttığını gözlemlemek mümkündür. Özellikle birtakım hümanistik coğrafyacılar arasında Edebiyat ve Coğrafya ilişkisine dair yapılan değerlendirmelerin yanında (Tuan, 1976; Tuan, 1990), Edebiyat Coğrafyası'nda haritaların rolüne dair yapılan çalışmalar da bulunmaktadır (Muehrcke ve Muehrcke, 1974).

1980'lere doğru, Edebiyat Coğrafyası çalışmaları giderek multidisipliner olma yönüyle belirginleştiği gibi, coğrafi görünümün veya peyzajın aktarılması üretilen çeşitli eserlerle devam ettirilmiştir (Salter ve Lloyd, 1977; Thrift, 1978; Pocock, 1981; Silk, 1984; Porteous, 1985; Herendeen, 1986). Edebiyat Coğrafyası alanında yakın zamandaki en somut gelişmelerden biri ise 2015 yılında ilk sayısı çıkan ve yılda iki kez yayımlanan "Literary Geographies" adlı bilimsel derginin yayın hayatına başlamasıdır. Derginin 2015 yılındaki ikinci sayısında Hones, Edebiyat Coğrafyası literatürünü değerlendirmektedir. Bu çalışma Edebiyat Coğrafyası alanında iki yazara ve onların çalışmalarına odaklanmaktadır. Bunlardan birincisi Marc Brosseaus'un 1994 yılında yazdığ 1 "Geography's Literature" adlı eser iken, diğeri Andrew Thackers'ın 2005'de yayımlanan "The Idea of a Critical Literary Geography” adlı çalışmasıdır. Brosseau çalışmasının ana amacının Coğrafya'ya edebiyatın nasıl entegre olacağına dair kapsamlı ve eleştirel bir değerlendirme önermek olduğunu belirtmektedir. Buna karşılık Thacker ise kökleri bugüne kadar uzanan Edebiyat Coğrafyası çalışmalarına eleştirel edebiyat coğrafyası yaklaşımını yerleştirmek olduğunu belirtmektedir. Ayrıca Hones, Joanne Sharp'in 2000 yılında yazdığı "Towards a Critical Analysis of Fictive Geographies" adlı eseri de eleştirel edebiyat coğrafyası çalışmalarından biri olarak değerlendirmektedir (Hones, 2015, s. 1-2). Bunlara ek olarak son zamanlarda Edebiyat Coğrafyası üzerine yapılmış ve ağılıkla çeşitli araştırıcıların katkı sunduğu çalışmalar da Edebiyat Coğrafyası'nın farklılaşan ve gelişen yönlerine örnek olarak gösterilebilir. (Aseguinolaza, 2003; Piatti, Reuschel, ve Hurni, 2009; Hones, 2010; Pocock, 2014; Peraldo, 2016). Son dönemde uluslararası alanda yapılan çalışmalar pratik incelemeleri ele almakta iken, aynı zamanda Edebiyat Coğrafyası, edebiyat kartografyası gibi teorik alandaki tartışmaları ve literatür değerlendirmelerini de içerecek şekilde genişlemektedir.

Türkiye'de Edebiyat Coğrafyası üzerine yapılan çalışmalar ise oldukça yenidir. Bu alanda yapılan çalışmalarda genellikle bir romanın Edebiyat ve Coğrafya ilişkisinin kurulup, incelenmesi esas alınmaktadır (Yılmaz, 2007; Cobutoğlu, 2014; Kaçmaz, 2017; Kaçmaz ve Kaçmaz, 2019). Özellikle Kaçmaz'ın çalışması (2017), Edebiyat Coğrafyası alanında yapılmış en güncel çalışmalardan birini oluşturmaktadır. Yazar çalışmasında Elif Şafak'ın romanlarında coğrafi yönelimin izlerini araştırmış ve bir nevi "coğrafya merkezli okuma (géolittéraire)" yapmıştır. Çalışma temel olarak üç bölümde ele alınmıştır. İlk bölümde teorik araştırmanın olduğu Edebiyat Coğrafyası, mekân gibi konular ele alınmakta iken, kalan diğer iki bölüm Elif Şafak'ın romanlarının coğrafi açıdan değerlendirilmesine ayrılmıştır. Özellikle çalışmanın ana omurgasını oluşturan ikinci bölümde Coğrafya'nın iki alt alanı olan Fiziki ve Beşeri Coğrafya özellikleri de göz önünde bulundurularak değerlendirilmiştir. Çalışmanın son bölümü ise şahıs ve coğrafi terim analizlerine ayrılmış olup, bu bölümde yer alan haritalar ise yazarın Edebiyat Coğrafyası'ndaki kartografik geleneği takip ettiğini göstermektedir (Kaçmaz, 2017).

\section{ORHAN KEMAL VE MEKÂN}

15 Eylül 1914 yılında Adana'nın Ceyhan ilçesinde doğan Orhan Kemal (Mehmet Raşit Öğ̈̈tçü), romanlarının yoğunlaştığı 1950-1970 yılları arasında çeşitli konularda eserler vermiştir. Eserlerinin beslendiği kaynak kendisinin hayat deneyimiyle sıkı bir bağlantı içerisinde olmuştur. Babasının Cumhuriyet'in ilk dönemlerinde hükümete karşı önemli bir siyasi figür olması, yazarın ve ailesinin hayatlarının bir döneminin sürgünde geçmesine sebebiyet vermiştir. Özellikle sürgün yılları ve daha sonra yaşadığı çeşitli göçler Orhan Kemal'in eserlerinin şekillenmesinde etkili olmuştur ${ }^{2}$. Beyrut'ta babasının

1 Coğrafya merkezli okuma, okuma türlerinden biridir. Bu okuma türünde eserdeki mekân coğrafya olarak ele alınmaktadır. Bu ele alışta insan ve edebiyata konu olan eserin mekândan bağımsız olmadığı tezi dikkate alınmaktadır. Nasıl ki insan yetiştiği coğrafyadan-yüzey şekilleri, iklim, bitki örtüsü vb.- etkileniyorsa, üretilen eser de bulunduğu bölgenin coğrafyasına göre şekillenmektedir. Dolayısıyla metindeki gerçek veya kurgusal mekânlara ait tasvirler, iklim, bitki örtüsü gibi fiziki coğrafi etmenlerin metnin içeriğiyle kurduğu ilişki, yazarın geçmiş mekânsal denemeleri coğrafya merkezli okumanın püf noktalarıdır (Kefeli, 2009).

2 Coğrafya merkezli okumalarda yazarın hayat coğrafyası, eserdeki mekânı anlamak açısından önem taşımaktadır (Kefeli, 2009). Orhan Kemal'in bu anlamda yaşadığı mekânlar eserlerinin mekânsal kurgusunda başrolü oynar. Adana, Beyrut ve İstanbul olmak üzere 3 șehirde yașamış yazarın özellikle romanlarındaki mekân seçimi ve bunların anlatım biçiminin hayatıyla sıkı bağlantı içerisinde olduğu anlaşılmaktadır. Özellikle gözlem yeteneğiyle birleşen mekânsal anlatımı eserlerinde dönemindeki birçok beşeri coğrafya etkeninin de anlaşılmasını sağlamaktadır. 
lokantasında, döndüğünde ise Adana'da Milli Mensucat Fabrikası'nda çalışması onun toplumu gözlemleyen romanlarının şekillenmesindeki ana etmenlerdir. Fakat 1940 yılının Aralık ayında Bursa Cezaevi'nde Nazım Hikmet ile tanışması romancılığının gelişimindeki önemli dönüm noktalarındandır (Kemal, 2012, s. 11-15). Orhan Kemal'in hareketli geçen hayatındaki son durak ise İstanbul'dur. Hayata veda edene kadar İstanbul'da yaşamını devam ettiren yazarın şehir ile kurduğu ilişki mekânsal ve toplumsal açıdan dikkat çekicidir.

Türkiye 1940'lı yılların sonunda NATO'ya girebilmek amacıyla Batı ile çeşitli ilişkiler kurmuş, bu durum çeşitli planlama çalışmalarının yapılmasını da beraberinde getirmiştir. 1946 Planı ve daha sonra yapılan 1947 İktisadi Kalkınma Planı bu dönemin ekonomi politikalarının planlama anlayışına yansıması olarak değerlendirilebilir (Avc1, 2000, s. 40). 1950 yllından sonra gerçekleşen politikalarda ise kırsal alanın kalkındırılmasına yönelik düzenlemeler ön plandadır. Fakat Türkiye'nin bu dönemdekiekonomipolitikalarındakırsalalanınkalkındırılmasında makineleşmeye verilen ayrı bir önem vardır. Kırsal alanda makineleşmeyle beraber köylerdeki nüfusun bir bölümü işsiz kalmış, bu durum şehirlere doğru yönelen göç hareketlerinin hızlanmasına ve sosyal düzeni bozacak etkilerin ortaya çıkmasına sebebiyet vermiştir (Yücel, 1961, s. 38). Kırsal alandaki makineleşme sayesinde traktör sayısının artması, tarımsal alanda işgücü fazlası oluşturmuştur. Buna ek olarak şehirlerde ithal ikameciliğe dayalı sanayileşme ucuz işgücüne olan ihtiyacı arttırmıştır. Hemen hemen aynı dönemde gerçekleşmiş olan bu değişimler şehirlerdeki işgücü ihtiyacının karşılanmasını da beraberinde getirmiş, şehirler hızlı bir şekilde nüfuslanmaya başlamıştır. İstanbul, İzmir, Ankara, Bursa, Adana ve Konya gibi şehirlerin nüfusu hızla artmıştır. Bunun neticesinde hem şehirlerde yaşayan nüfusun sayısında, hem de toplam nüfus içinde şehirlerde yaşayanların oranında artışlar gerçekleşmiş̧ir (Avc1, 2005, s. 8). Mekânsal anlamda ise gecekondular yerleşim birimi olarak öne çıkmış, büyük şehirlerin çehresini değiştirmiş ve bu şehirlerdeki nüfus artışında rol oynamıştır (Darkot, 1961, s. 12). Orhan Kemal Türkiye'nin 1950'lerden sonra hızla artan bu şehirleşme sürecini eserlerine en iyi aktaran yazarların başında gelmektedir.

Mekân toplumsal yaşam içerisinde önemli bir konumda olmasına karşıllık, roman başta olmak üzere çeşitli edebi türlerde de önemli bir öge olarak karşımıza çıkmaktadır. Özellikle romanlarda mekân tercihi roman karakterlerinin seçimi, bu karakterlerin kişiliklerinin belirlenmesi, romanın ve beraberinde kişilerin sosyo-ekonomik yapılarının belirlenmesinde rol oynar (Uyar, 2015, s. 44; Yılmaz, 2007, s. 17). Romanlarda mekânların tasvir edilmesi ve mekân- insan ilişkilerinin ele alınması da en nihayetinde konusal açıdan coğrafyacıların ilgisini çeker. Yazar için dekor, coğrafyacı için ise coğrafi görünüm olarak ifade edilebilecek bu durum, coğrafyacıları edebiyata, en çok da romana çeken unsurların başında gelmektedir (Kaçmaz, 2017, s. 20).

Edebi eserlerde olayın geçtiği mekânı coğrafi açıdan ayırabileceğimiz üst başlıklarından birini şehirsel ve kırsal mekân olarak ele almak mümkündür. Özellikle günümüzde şehrin baskın karakterinin artmış olması, onun romanlardaki mekân seçiminde oynadığı rolü de arttırmaktadır. Alver yaptı̆̆ 1 çalışmasında romanın yeni bir tür olarak şehirle kendisini bulduğunu belirtir (Alver, 2009, s. 67). Şehir, roman başta olmak üzere çeşitli eserlerde insanın içinde bulunduğu toplumsal, siyasal, ekonomik şartlarla beraber değerlendirilir. Kırsal yaşama göre şehirde insanın bireyselleşmesi, zayıflayan dayanışma ağlarının da etkisiyle yaşama tutunma çabası çok daha belirgindir. Dolayısıyla şehrin eserlere yansıyış biçimi ağırlıkla bu tutunma çabasının şekillendiği olumsuz bir ortamda gerçekleşir.

Orhan Kemal'in eserlerindeki anlatımın mekânsal yansıması da kendisini belli eder. Eserlerinde kırsal ve daha ağırlıkla şehirsel olmak üzere iki temel yerleşme kalıbının anlatımı dikkat çeker. Kırsal alan yazarın eserlerinde geçim sıkıntısı ve bununla bağlantılı olarak verilen göçlerle karakterize olur. Şehir ise ağırlıkla negatif vurgularıyla belirginleşmektedir. Özellikle bu çalışmaya konu olan romanlarında yazar şehri ahırda yaşanılan, gerektiğinde orada doğum yapılan, çamaşır kazanlarında yemeklerin yapıldığı, kadının meta konumuna indirgendiğ yerleşme alanı olarak anlatır. $\mathrm{Bu}$ anlatım biçimi toplumsal gerçekçi bir yazar için şehir hayatının tüm çarpıklıklarıyla okuyucuya tanıtılmasını sağlamaktadır.

Orhan Kemal'in eserlerinde kırsal ve şehirsel mekân tekrardan mekânsal iki kategorik ayrıma tabi tutulabilir. Bu kategorik ayrımdan birincisi Adana ve çevresini ele alan eserlerken, diğeri ise İstanbul'u ele alan eserlerdir. Orhan Kemal mekânsal açıdan Adana'ya odaklandığı eserlerinde otobiyografik ve sosyal eleştirel olmak üzere ikili bir yapı takip etmiştir (Narlı, 2012, s. 105-106). Sosyal eleştirel perspektifte yaklaştığı eserlerinde Çukurova gerçekliğini ağırlıklı olarak yansıtır. Buna ek olarak tarıma dayalı sanayinin gelişimi de vurgulanan konular arasındadır. Özellikle Türkiye'nin çeşitli köylerinden ve şehirlerinden Çukurova'ya gelmiş insanların karşılaştıkları zorluklar, sınıfsal gerçeklikleri içinde işlenir. Benzer durum İstanbul ile ilgili romanlarda da karşımıza çıkar. İstanbul romanlarında imar hareketleri, köylü-şehirli çatışması, gecekondular ve yoksulluk gibi birçok farklı tema dikkat çeker. Bunu yaparken hem Adana'da hem de İstanbul'da mikro alanlara 
odaklanması yazarın mekânsal gözlem açısından da başarılı olduğunu göstermektedir. Bu iki farklı şehre odaklanan romanlardaki mekânsal tercihler de Orhan Kemal'in yönelimini anlamak açısından önemlidir. Şehir ile kurduğu bağda fabrikalar ve bunların etrafindaki mahalleler, ticaret mekânları olarak manifatura dükkânı, eskici dükkânı, çaycı dükkânları ayrıca meydanlar, dini ve kültürel mekânlar eserlerindeki anlatımda karşımıza sık sık çıkmaktadır.

\section{BULGULAR VE ANALIZZ}

Orhan Kemal'in "Bereketli Topraklar Üzerinde" ve "Gurbet Kuşları" romanları belirli kodlar etrafında coğrafi bir perspektif ekseninde değerlendirilmiştir. Her iki romanda da şehirsel coğrafi unsurlara uygun olarak çeşitli kodlar oluşturulmuştur ${ }^{3}$ (Şekil 1). 1950'li y1llardan sonra Türkiye'de kırsal alanda makineleşmeye bağlı olarak gerçekleşen değişiklikler "kırdan şehre göç" adı altında ayrı bir kodlanma yapılması ihtiyacını doğurmuştur. Bu kod hem romanda hem de toplumsal gerçeklikte kendisini belirgin kılmaktadır. İkinci kod olan "şehir içi imar hareketleri”" Türkiye'de sadece 1950'li yıllar sonrasında değil, Cumhuriyet'in ilk kuruluş yıllarına denk gelen süreçte de gözlemlenen bir olgudur. Fakat özellikle "Gurbet Kuşları" romanında konu ve zaman seçimi açısından ilgili kodun kullanımı 1950 sonrası dönemde geçmektedir. Demokrat Parti döneminde açılan geniş bulvarlar, caddeler, hızlı gelişen konut inşa süreçleri bu kodlamanın roman özelindeki alt unsurlarını oluşturmaktadır. Bundan sonra oluşturulanüçkodolan "şehirsel fonksiyonlar", "gecekondulaşma" ve "şehirsel coğrafi görünüm" hem bu önceki iki kodla bağımsız, hem de bağımlı olma ilişkisi içerisindedir. Özellikle bu aşamada hiyerarşik bir ayrıma gidilerek şehirsel fonksiyonlar literatüre bağlı kalınarak beşli alt bir ayrıma tabi tutulmuştur. Bunlar "sanayi fonksiyonu", "ulaşım fonksiyonu", "ticaret fonksiyonu", "tarım fonksiyonu”, "konut fonksiyonu” dur (Şekil 1).

Romanlarda kelime analizlerini yapabilmek için ise ilgili dönemde toplumsal yaşam içerisinde belirginleşmiş ve coğrafi karşılıkları olan birtakım kelimeler seçilmiştir. Bu kelimeler "şehir", "İstanbul”, “fabrika", "gecekondu”, "Çukurova", "gurbet", "traktör" ve "göç"tür. İlgili kelimelerin her iki romanda da geçiş sıklıkları kendi içerisinde değerlendirilmiş̧ir. İlgili kelimelerden hareketle kodların kendi içerisindeki oransal dağılımı ve kodlanma sıklıkları gösterilmiştir (Şekil 6).

Orhan Kemal'in "Bereketli Topraklar Üzerinde" ve "Gurbet Kuşları" romanları birbirinin devamı niteliğindedir. Her iki romandaki çıkış noktası kırsal alandaki ekonomik sıkıntılara bağlı olarak şehirlere doğru gerçekleşen göçler ve bu göçler sonrasında göç edenlerin şehir hayatıyla karşılaşmalarıdır. "Bereketli Topraklar Üzerinde" romanında üç köylünün gerçekleştirdiği göçler kısa sürelidir. Yani bir nevi köye dönme isteği ve köye bağlılık söz konusudur. Bu durum Yücel (1961)'de köylünün doğup büyüdüğü, havasını soluduğu yerle bağlantısını koparmak istememesine, ayrıca havası, suyu, manzarası kendi köyünü andıran yerlere göç etme isteğine bağlanmaktadır (Yücel, 1961, s. 31). Gültekin (2011)'de ise romanda gerçekleşen bu göç hareketliliği, tarımda makineleşmenin henüz başlangıç aşamasında olması ile açıklanmaktadır (Gültekin, 2011, s. 202). "Bereketli Topraklar Üzerinde" romanında gerçekleşen göç, Sivas'ın Ç. Köyü'nden Adana'ya (Çukurova'ya) doğru gerçekleşmektedir. Romanda karakterlerin şehirle kurdukları ilişki şehirsel alandaki fonksiyonel çeşitliliği göstermesi açısından dikkat çekicidir. Sivas'tan göç eden üç arkadaş ilk önce fabrikada çalışmaktadır. Yazarın Adana'nın tarıma dayalı sanayisini göstermesi açısından kitabın bu bölümleri ilgi çekicidir. Bu dönemde Türkiye'nin birçok yerinde yaygınlık kazanan tarıma dayalı sanayi, Adana'da pamuk özelinde belirgin hale gelmektedir. Kitabın bu bölümü yazarın Adana'da hızla artan sanayi fonksiyonuna dikkat çekmektedir.

Bereketli Topraklar Üzerinde romanında karakterlerin çeşitli sebeplerle fabrikadaki iş hayatının sonlanması, şehir içindeki yeni bir fonksiyonun okuyucuya tanıtılmasına da imkân tanımaktadır. Kitabın gelişim seyri bu aşamada konut inşa

3 İlgili kodların oluşturulmasında referans alınan en önemli kaynak romanların yazıldı̆̆ tarihsel döneme karşılık gelen 1950-1980 arasında yapılmış coğrafya çalışmalarıdır. Özellikle 1940'ların ortalarında başlayan Şehir Coğrafyası'na ait çalışmalar bu dönemde coğrafyacıların şehre dair çalışmalarının ana hatlarını da yansıtmaktadır. 1950'li yıllardan sonra Türkiye'de şehirleşme hareketlerinin hızlanmasına paralel olarak yapılan ilk çalışmalar çeşitli nüfus sayımları üzerinden Türkiye'de gerçekleşen değişimi anlamaya odaklanmıştır. Bu ilk çalışmalardaki tespitler kırdan şehre göçü İstanbul, İzmir, Ankara, Adana, Eskişehir gibi şehirler üzerinden sonuca bağlanmaktadır. Ayrıca bölgesel birtakım tespitler de yapılmakta, şehirleșmenin nedenleri sorgulanmakta ve çeşitli dağılıș haritaları ile durum açıklanmaktadır (Selen, 1945; Darkot, 1956; Öngör, 1958, Tümertekin ve Tunçdilek, 1961). Aynı devreler içinde yapılmış ve daha mikro alanı örneklem seçmiş çalışmalar bulunmasına rağmen (İnandık, 1956; Tunçdilek, 1957) bu çalıșmalar yöntemsel açıdan öncekilerle benzer olduğu gibi konu açısından ağırlıkla kırsal alanlara odaklanmaktadır. Özellikle 1960’lı yılların başı ile beraber coğrafyacıların şehir alanındaki çalışmalarında daha spesifik ve mikro çalışma alanları oluşmuştur. Dolayısıyla elde edilen bulgular da daha belirgin hale gelmiştir. Bu dönem çalışmalarında şehirleşmenin nedenleri kırdan şehre göç, sanayileşme gibi unsurlarla açılanmış (Yücel, 1960), makineleşme, gecekondulaşma, șehirsel fonksiyon gibi kavramlarla Türkiye şehirleşmesinin kendine özgü özellikleri de ortaya konulmuştur (Yücel, 1961; Öngör, 1961; Darkot, 1961; Tümertekin, 1965; Tuncel, 1973; Sergün, 1974-1977; Şen, 1974, Korkut 1974; Tümertekin 1977). Fakat bu dönem içinde yapılmış bazı çalışmalar coğrafyacıların şehir çalışmalarının mikro alanlara odaklandığını ve daha uygulamalı hale geldiğini doğrulamaktadır. Emiroğlu, (1963)’te Zonguldak ve Batı Karadeniz Bölümü, Sözer, (1967)'de Erzurum, Tuncel (1973)'de İzmit, Şen, (1974)'te ise Ankara şehri nüfus hareketleri ve şehirleşme süreçleri üzerinden ele alınmaktadır. Bu çalışmalardaki kırdan şehre göç, gecekondu, sanayi vurgusu daha önce yapılmış birçok çalışmadan daha belirgin haldedir. 
süreçleri üzerinden şekillenmektedir. Karakterler şehir içindeki bir binanın inşasında çalışmaktadır. Yazarın gerçekçi gözlemlerinin somut bir ifadesi olan bu bölümlerdeki anlatımlardan biri barınma koşullarına ilişkindir. Romanda karakterlerin barınma koşulları insani yaşam şartlarının çok dışındadır. Ucuz işgücü olarak şehre gelmiş birçok kişi ahırlarda veya bir kişinin işlettiği ve bir odayı birden fazla iş̧̧inin kullandığı yerlerde yaşamaktadır.

Yazarın kitabında Adana'yla ilgili olarak anlattığı üçüncü belirgin fonksiyon tarımdır. Özellikle Çukurova'daki pamuk tarımı ve burada gerçekleşen olaylar kitabın son aşamasındaki gelişimi özetlemektedir. Yazarın bu aşamada vurguladığı dikkat çekici bir gerçeklik de tarımda makineleşmeye yöneliktir. Hatta romanın kahramanlarından birinin son bölümde kolunu patoz makinesine kaptırıp, hayatını kaybetmesi tarımda makineleşmenin okuyucuya aktarımı açısından dramatik bir sahnedir.

İlgili kodlara göre oluşturulmuş Tek Vaka Modeli'ne göre romanda sanayi fonksiyonu 21 kez kodlanarak ilk siray almaktadır. "Bereketli Topraklar Üzerinde" yazarın mekânsal olarak olayın Adana'da geçtiği romanlarındandır. Dolayısıyla Çukurova'da üretimi yapılan pamuğa bağlı olarak gerçekleşen tarıma dayalı sanayi olgusu karşımıza çıkmaktadır. Yazar, kitapta tarıma dayalı sanayi ile ilgili olan bölümleri Çırçır Fabrikası özelinde vurgulamaktadır. Kitapta roman kahramanlarının şehirde ilk karşılaştıkları yerin fabrika olması kodlanma sayısındaki artışın nedenidir (Şekil 2). Ayrıca sanayi fonksiyonunun geçtiği bölümlerden birine örnek şu şekilde verilebilir: "Dahası şu ki burası şehir, fabrika. Köy yerine benzemez. Hemşeri memşeri... Geç bir kalem. Elin ayağın tutuyor mu, gücün kuvvetin yerinde mi, iş başına git, iş varsa versin. Lakin şu sıra pek aklım kesmez. Fabrikanın önü işsiz dolu. Boyuna adam çıkarıyorlar işten! (Kemal, 2018a, s. 50).

Bereketli Topraklar Üzerinde romanı kırdan şehre gerçekleşen göç sürecini ve daha sonra gerçekleşen olayları anlatmaktadır. Dolayısıyla ilgili kodların sayısal dağılımında kırdan şehre göçün 16 defa kodlanarak en fazla öne çıkan ikinci kod olduğu anlaşılmaktadır (Şekil 2). Romanda kodlanan ilgili bölümlerdeki göçe yapılan coğrafi vurgu da dikkat çekmektedir. Yazar, romanda göçle kurduğu ilişkiyi kitabında şöyle örneklendirmektedir. "Orta Anadolu'nun seksen evlik köylerinden Ç.Köyü'nün erkekleri o yll da çalışmak için çeşitli iş bölgelerine dăğldılar" (Kemal, 2018a, s. 7), “ Bu sekiz ırgat da çalışmak için Çukurova'ya inmiş, Orta Anadolu ya da doğu illerimizdendir; yakın çırçır fabrikalarında çalışıyorlardı"
(Kemal, 2018a, s. 71). Bu anlatımlar yazarın tanık olduğu göç olgusunun coğrafi karşılıklarını oluşturmaktadır. Kitapta yapılan Orta Anadolu vurgusu göçün ilk etapta yakın merkezlere yapılma eğilimiyle paralellik taşımaktadır.

Romanda ulaşım fonksiyonu üçüncü en fazla kodlanmayı oluşturmaktadır (Şekil 2). Özellikle şehir içi ulaşım vurgusu bu kodlanma açısından dikkat çekicidir. Yazar 1950'li yılların Adana'sını romanında ulaşım açısından şu sözlerle anlatmaktadır: "Elinde bavul, peron merdivenlerini ağır ağır indi. Şehre müsteri bekleyen otobüs, taksi, çift atl fayton kalabalı̆̆ının bekleştĭgi meydanı geçip halkın Holivut Mahallesi banka evleriyle kalın bedenli okaliptüs ağaçlarının altına geldi. Kendisi gibi tren bekleşen ırgatların arasına geçti. O kadar çoktular ki" (Kemal, 2018a, s. 372).

Kitapta tarım fonksiyonun belirginleştiği bölüm kahramanların kitabın sonunda Çukurova'da ırgat olarak çalışmasının anlatıldığı son bölüme denk gelmektedir. Tarım fonksiyonu ise kitapta $4 \mathrm{kez}$ kodlanmıştır (Şekil 2). Özellikle fabrika ve inşaattan sonra karakterlerin tarımsal alanda ırgat rolüne bürünmesi yazarın iyi gözlem yeteneği ve yaşadığı yerin özelliklerine hâkim olmasıyla yakından ilgilidir. Kitapta tarım fonksiyonuyla ilgili olan kodlamalardan biri şöyledir: "Bu mevsim pamuk tohumunun toprağa atıldı̆ğ mevsimdir. Kara kazmaya dört beş hafta vardır daha... Büyük toprak sahipleri doğu illerimize elçileri gönderip tellallar çağırtırlar ki'... Çukurova'da bu yıl iş çoktur. Haftalıklar yüksek bildikleri gibi değil!'Pek pek birkaç hafta sonra 'Urundan Şandan' çekilip çekilip gelen irgat kafilelerinin akın başlar. Binlerce kadın, erkek, çoluk, çocuk, genç, yaşll, paramparça üst başlarlyla pis pis kokarak, Ötegeçe'deki mezarlığa ylğılırlar. Kışı çıplak çocuklar mezar taşlarına inerler tevekkül içindeki kadınlar, Taşköprü'nün bu gecesindeki rrgat pazarından iş ve ekmeğin sevinciyle gelecek erkeklerini bekleşirler" (Kemal, 2018a, s. 168).

Şehirsel coğrafi görünüm romanda 4 kez kodlanmıştır (Şekil 2). Yazarın kitapta şehirsel coğrafi görünüm anlamında belirgin bir vurgusu yoktur. Genellikle kitapta anlatılan, bir mekânın yer aldığı mahallenin, caddenin tasviri veya belirgin özellikleridir. Kitapta son olarak ticaret fonksiyonu $1 \mathrm{kez}$, konut fonksiyonu ise 2 kez kodlanmıştır (Şekil 2). Her iki fonksiyona da kitapta münferit yerlerde değinilmiştir.

Seçilen kelimelerden hareketle "Bereketli Topraklar Üzerinde" romanında en fazla kullanılan kelimelerin analizi yapılmıştır. Buna göre şehir 116, fabrika 104, Çukurova 57, traktör 21, gurbet 35, göç 3, İstanbul $1 \mathrm{kez}$, gecekondu ise hiç kullanılmamıştır (Şekil 3). Kelime sıklıklarının oransal 
dağılımına bakıldığında şehir \%35, fabrika $\% 31$, Çukurova $\% 17$, gurbet $\% 10$, traktör $\% 6$, göç $\% 1$, İstanbul $\% 0,3$, gecekondu ise $\% 0$ 'lık bir orana sahiptir.

"Bereketli Topraklar Üzerinde" romanında kelimelerin geçiş sıklıklarının metne göre dağılımına bakıldığında şehrin ağılıkla göç edilecek yeri tanımlandığı görülmektedir. Buna karşılık yazar şehri ağırlıkla toplumsal açıdan betimlemektedir. Şehir, roman karakterlerine göre temkinli olunması gereken karmaşı bir yerleşmedir. Özellikle romanın ilk bölümlerinde şehirle beraber vurgulanan kelimelerin başında fabrika gelmektedir. Karakterlerin şehirle ilk tanışmalarının sanayi fonksiyonu üzerinden gerçekleşmesi fabrikanın şehirle beraber öne çıkmasını sağlamaktadır. Çukurova belirlenen kelimeler arasında sıklık açısından üçüncü sıradadır. Çukurova romanda ağırlıkla göç edilen alanı temsil etmekle beraber, romanın son bölümünde karakterlerin tarımsal alanda çalışmalarıyla ön plana çıkmaktadır. Yazarın her iki romanı da konusal olarak kırdan şehre göçe odaklanmasına rağmen göç kelimesi "Bereketli Topraklar Üzerinde" romanında sadece 3 defa kullanılmıştır. Buna karşılık yazar göç kelimesiyle ifade edeceği yerleri gurbet sözcügüyle anlatmaktadır. Terimsel olarak gurbet bir romanda daha edebi birtakım çağrışımlara atıf yapar. Gurbet, romanda karakterlerinin köyle olan duygusal bağını da yansıtmaktadır. Traktör kelimesi ilgili kelimeler arasında \%6'llk bir orana sahiptir. Traktör kelimesinin geçtiği yerler romanın son bölümlerindeki kırsal alanın anlatıldığı bölümlere tekabül etmektedir. Yazar, romanında traktörü göçe sebebiyet verecek bir etken olarak değerlendirmemiştir. Gecekondu ve İstanbul kelimeleri ise toplamda sadece $1 \mathrm{kez}$ kullanılmıştır. Bu kelimeler romanın yönelimini de açıklamaktadır. İstanbul, yazarın mekânsal açıdan tercih ettiği roman kategorilerinde ayrı bir başlıktadır. Bu açıdan yazar Adana temalı bu romanında İstanbul'u anlatmayı tercih etmemiştir. Dolayısıyla 1950'li yıllarda başta İstanbul, İzmir ve Ankara'da belirgin hale gelen gecekondu olgusunun Adana'nın anlatıldığ 1 Bereketli Topraklar Üzerinde romanında belirginleşmediğini görmek mümkündür.

"Gurbet Kuşları", "Bereketli Topraklar Üzerinde" romanın devamı niteliğindedir. Roman, çıkış noktası olarak kırdan şehre yapılan göçü anlatmaktadır. Fakat yapılan göçün mekânsal boyutu değişmekte, bu romanda mesafe olarak daha uzak olan İstanbul'a göç edilmektedir. Romanın ana kahramanlarından olan İflahsızın Memed etrafında şekillenen romanda İstanbul'a yapılan göç sonrası şehirde gelişen olaylar ele alınmaktadır.

İlgili kodlara göre oluşturulmuş Tek Vaka Modeli'ne göre "Gurbet Kuşları" romanında "kırdan şehre göç" 19 defa kodlanarak en fazla kodlama yapılan başlığı oluşturmaktadır (Şekil 4). Yazarın romanda kırdan şehre göçü anlattığı bölümlere şöyle bir örnek verilebilir: "Sen her yll gelir misin İstanbul'a? Ben mi? Gelirim. Hangi köyden olursun? Divriği'nin köylüğünden. Bu İstanbul'da bizim hemşeriler çok. Unkapanı'nda eyleşirler çokluk. Kayfe var orda bizim hemşerilerin. Pehlivanın kayfesi. Kayfenin ardinda yatardim ben ya bakma" (Kemal, 2018b, s. 33), “Iflahsızın Memed'i getiren 'Kuşluk Treni'nden sonra gene her hafta kuşluk trenleri ta Kurtalan'dan kalkıp, yolları üzerindeki irili ufaklı istasyonlardan topladıkları çeşitli yolcularla Haydarpaşa Garı'na çı̆̆lık çığlığa girmeye, ıslak fisllttlarla raylar üzerine upuzun serilip kalmaya devam ettiler. Gene koşanlar, gene koşuşanlar oldu. Koşanlarla koşuşanlar arasında istasyon görevlilerinden başka gene gar hamallarl, yolcularını karşılamaya gelmiş fötr şapkalı, tayyörlü, mantolular..." (Kemal, 2018b, s. 245). Yazar göçü şehirdeki hemşerilik ilişkileri, göç alınan ve veren yerler gibi birçok unsurla destekleyerek anlatmaktadır. Ayrıca romanda Haydarpaşa, Divriği, İstanbul ve Unkapanı gibi vurgulanan yerler de dikkat çekmektedir.

Romanda "gecekondulaşma" 13 kez kodlanmıştır (Şekil 4). Gecekondu olgusu Türkiye'nin şehirleşme sürecinde deneyimlediği kendiliğinden ve kaçak olarak ortaya çıkan yerleşmeler olarak tanımlanabilir. Yazar, romanında gecekondulaşmayı son bölümlerde coğrafi karşıllğıını göstererek vurgulamaktadır. İstanbul'a ucuz işgücü olarak gelmiş İflahsızın Memed'in şehirde tutunduktan sonra barınma problemini çözmek amaciyla başvurduğu ilk araç gecekondudur. Zeytinburnu İstanbul'un ilk gecekondu yerleşmeleri arasındadır. Romandaki gecekondulaşma olgusunun geçtĭgi mekân da Zeytinburnu'dur. Zeytinburnu'nda geçen gecekondulaşma sürecini yazar şöyle anlatmaktadır: "Güneş iyice devrilip, karanlık alacasl Zeytinburnu gecekondularını yutunca, Hatce küçük gemici fenerini yaktı, gecekondularının duvarındaki her zamanki çiviye asti" (Kemal, 2018b, s. 314), "Zeytinburnu, gecekondular. Hatça Ablasıgilin gecekondusu gerilerdeydi. Sırtını trenin başını alıp gittiği yöne dönmüss, iki odalı, bir salonlu. Salon dediyse hani sözün gelişi. Ufacık duvarları sivasız" (Kemal, 2018b, s. 154).

Şehir içi imar hareketleri romanda 13 kez kodlanmıştır (Şekil 4). Yazarın şehirdeki imar faaliyetlerine bakış açısı aynı zamanda romanın politik yönlerinden birini de oluşturmaktadır. Özellikle Demokrat Parti döneminde geniş yolların ve caddelerin açılması, şehirde gerçekleşen büyük yıkımlar yazar tarafından romana aktarılmıştır. Ayrıca bu istimlak sürecinde tarihsel yapıların yıkımı da yazar tarafindan okuyucuya aktarılmaktadır. Yazar 
şehir içindeki imar faaliyetlerini romanında şu şekilde açıklamaktadır: "Işste Atatürk'ten sonra en büyük Türk'ün nurlu eli İstanbul'u taş taş üstünde koymamacasına ylkıp yeniden yapmak için harekete geçmiş, dev makineler hayırlı istimlakin dev makineleri tarihsel kocaman kocaman yapulara toslamaya başlamıştı" (Kemal, 2018b, s. 51).

Ulaşım fonksiyonu Gurbet Kuşları romanında $11 \mathrm{kez}$ kodlanmıştır (Şekil 4). Bu kod kapsamında romanda ulaşım fonksiyonu şehir içindeki ulaşım faaliyetleri olarak ele alınmıştır. Özellikle 1950'li yıllardan sonra gelişim ivmesini arttıran İstanbul'da ulaşımın işlevselliği ve çeşitliliği artmıştır. Yazar romanında karayolu, denizyolu, demiryoluna ait ulaşım araçlarının birçoğunu şehir içindeki işlevselliğini de göz önünde bulundurarak okuyucuya aktarmıştır. Ayrıca İstanbul'daki ulaşımın aktarımına dair şöyle bir bölüm örnek verilebilir: "Istanbul'da tomofil var, tramba var. Sen trambay nirden bilecen? Tramba bir tren. Trambanin yolu tipk tıpkisina treninki. Bi gidiyor ki. Sen İstanbul'u bi görsen yangina kalırsin Allah 'ıma. İstanbul gibi var mı?", "Kendine geldi. Vapur iskeleye ăgır ă̆ır yanaşmıştı. İskeledeki demir babalara geçirilen halatlar... Bu vapur dedikleri de beygir gibi, canl. Beygiri nasıl yularından bağlarlarsa, vapuru da bağllyorlardı. Vapurdan kalabalıkla birlikte yürüdü’ (Kemal, 2018b, s. 138).

Sanayi fonksiyonu romanda $8 \mathrm{kez}$ kodlanmıştır (Şekil 4). Sanayinin İstanbul'da fabrikaların hızla arttı̆̆ bir dönemde az kodlanmış olması, romanın ana karakterinin çalıştı̆̆ işin inşaat sektörü (bina yapımı) olmasıyla yakından ilgilidir. Dolayısıyla romanda şehir-sanayi ilişkisi çeşitli yerlerde belirtilen detaylarla sınırlı kalmıştır. Bu anlatımlardan biri şu şekildedir: "Partiden de yardım görünce, değirmen Çukurova'daki fabrikalardan Milli Mensucat'ın çırçırları gibi olup çıkmıştı. Milli Mensucat deyince... İlk zamanlar az paralarını almamıştı. Hey gidi günler Hey!" (Kemal, 2018b, s. 284).

Yazarın şehirsel coğrafi görünüm altında romanın çeşitli yerlerinde yaptığı anlatımlar İstanbul'un cadde, sokak, mahalle görünümlerini anlatmaktadır. Şehirsel coğrafi görünüm kodu romanda 4 kez kodlanmıştır (Şekil 4). Bu anlatıma şöyle bir örnek verilebilir: "Atatürk'ten sonra en büyük Türk işbaşındaydl. Ylllar yıll gazeteler İstanbul'un dar sokaklarında, trafiği aksatan bol dönemeçli, eğri büğrü caddelerden yakınmıyor, karikatürler yapmiyorlar miydl?" (Kemal, 2018b, s. 51).

Romanda ticaret fonksiyonu 4 kez kodlanmıştır (Şekil 4). Ticaret fonksiyonu romanda göç eden İflahsızın Memed'in şehirle ilk tanışmasında belirginleşmektedir. Hemşerilik ilişkilerini kullanarak şehirde tutunmaya çalışan roman kahramanın ilk durağı sebze-meyve hali olmaktadır. Dolayısıyla buradaki ticaret fonksiyonu yazar tarafindan anlatılmaktadır.

"Gurbet Kuşları" romanında seçilmiş kelimeler olan İstanbul 170, Çukurova 61 , gurbet 57 , şehir 55 , gecekondu 28 , fabrika 28 , göç 1 kere kullanılmış, traktör ise hiç kullanılmamıştır (Şekil 3). Kelime sıklıklarının oransal dağılımına bakıldığında İstanbul $\% 43$, Çukurova $\% 15$, gurbet $\% 13$, şehir $\% 14$, gecekondu $\% 7$, fabrika $\% 7$, göç $\% 0,25$, traktör $\% 0{ }^{\prime} l 1 k$ bir orana sahiptir.

"Gurbet Kuşları" romanında kelimelerin geçiş sıklıklarının romana dağılımına bakıldığında İstanbul'a yapılan vurgu dikkat çekmektedir. İstanbul kelimesi romanda $170 \mathrm{kez}$ geçmektedir. İstanbul sözcüğü "Gurbet Kuşları" romanında yazar tarafından negatif ve pozitif tarafları dikkate alınarak değerlendirilmiştir. Özellikle kırdan şehre göç bağlamında İstanbul, nihai bir varış noktası olarak ele alınmakta ve İstanbul'a göç sık sık “taşı toprağı altın" metaforuyla anlatılmaktadır. Fakat özellikle romanın gelişim sürecinde İstanbul içinde yaşayanlar açısından yaşanması zor, yaşam mücadelesinin çetin olduğu bir şehir olarak sunulmaktadır. Ayrıca İstanbul temalı bir romanda Çukurova'nın $\% 15$ 'lik bir orana sahip olması dikkat çekicidir. Çukurova kısa süreli göç edilen yere karşılık gelirken, İstanbul ise kalıcı olarak yapılan göçe karşılık gelmektedir. Dolayısıyla romanda yazar, Çukurova'yı anlatırken roman kahramanlarının gözünden bir kıyaslama yapmayı tercih etmiştir. Romanda İstanbul'a göç etmiş olan İflahsızın Memed için İstanbul Çukurova'dan daha iyi istihdam koşullarına sahiptir. Bu durum yazarın şehre atfettiği fonksiyonel çeşitlilikle yakından ilgilidir. Buna karşıllık ilk romanda İflahsızın Yusuf karakteri için bir yere kadar Çukurova üstün durumdayken, İstanbul' la tanışma her iki roman karakterinin de İstanbul'la kurduğu bağın kalıcı olmasını sağlamıştır.

Orhan Kemal'in diğer romanlarında olduğu gibi "Gurbet Kuşları" romanında da göç kavramı edebi bir bakış açısıyla yansıtılmaktadır. Bu bakış açısı romanda kendisini göç kelimesi yerine gurbet kelimesinin kullanımıyla göstermektedir. Gurbet, roman karakterlerinin köyle olan duygusal bağlayıcıllığını anlatması bakımından önemlidir. Romandaki birçok yerde yazarın bu durumu anlattığını görmek mümkündür. Romanda gurbet kelimesi 57 defa geçmekteyken, göç sadece 1 defa geçmektedir. Yazarın gurbet ve göç ilişkisini anlattığı en özlü kelimesi kuşluk trenidir. Kuşluk treni, kırdan şehre yapılan göçün benzetim açısından güzel bir örneğini oluşturmaktadır.

İki vaka modeli, incelenmek istenen iki olgunun karşılaştırılıp birtakım sonuçlara ulaşılmasını sağlar. Her iki romanın şehirsel 
coğrafi unsurlar açısından kodlamalarda birleştiği ve ayrıştığ noktalar bulunmaktadır. Belirlenen ortak kodlar çerçevesinde elde edilen kodlamalar sonucunda kırdan şehre göç, sanayi fonksiyonu, ulaşım fonksiyonu, şehirsel coğrafi görünüm ve ticaret fonksiyonunun her iki romanın da ortak kodları olduğu anlaşılmaktadır. Buna karşılık tarım fonksiyonu ve konut fonksiyonuna dair anlatımlar sadece "Bereketli Topraklar Üzerinde" romanının ilgi alanına girerken, gecekondulaşma ve şehir içi imar hareketleri de sadece "Gurbet Kuşları" romanın anlatımı olarak kalmıştır. Burada dikkat çekici bir detay ise İstanbul ve Adana'nın gelişim farklılıklarının romanlara yansımasıdır. Şehir içi imar hareketleri ve gecekondulaşma Türkiye'de ilk olarak İstanbul, Ankara ve İzmir'de belirgin hale gelmiştir. Dolayısıyla mekân olarak İstanbul'a odaklanan "Gurbet Kuşları" romanında gecekondulaşma ve şehir içi imar hareketleri spesifik bir durum arz etmektedir. Buna karşıllık "Bereketli Topraklar Üzerinde" romanı Adana'ya (Çukurova'ya) odaklanmaktadır. Tarım fonksiyonunun bu romanda işlenmesi romanın genel karakterine uygun bir durum oluşturmaktadır (Şekil 5).

Ayrıca romanlar için oluşturulan ortak kelimelerin her iki roman içindeki dağılımına bakıldığında şehir ve İstanbul kelimelerinin kodlanma sıklığı açısından \%24'lük bir paya sahip oldukları anlaşılmaktadır. Bunları fabrika \%18, Çukurova \%16, gurbet $\% 12,5$, gecekondu $\% 3,8$, traktör $\% 2,8$, göç $\% 0,5$ lik bir oranla takip etmektedir (Şekil 6).

Edebiyat kartografyası veya romanda geçen mekân ve yerlere bağlı olarak oluşturulacak haritalar Edebiyat Coğrafyası çalışmanlarında önemli bir yer tutmaktadır. Orhan Kemal'in "Gurbet Kuşları" romanı yazarın İstanbul'u mekân olarak seçtiği eserlerinin arasında gelmektedir. "Ben gördügümü yazarım" diyen yazarın romandaki yer ve mekân seçimleri de bu gerçekliği doğrudan yansıtmaktadır. "Gurbet Kuşları" romanında İstanbul'un birçok ilçesinin, mahallesinin, sokağının ve semtinin okuyucuya aktarıldığı dikkat çekmektedir (Şekil 7). Zeytinburnu ve Beyoğlu başta olmak üzere Bahçelievler, Bakırköy, Beşiktaş, Eyüp ve Sarıyer de yazarın anlatımında olayların geçtiği semtlere örnek olarak gösterilebilir. Bu ilçelerin mahalleri de olayların geçtiği daha alt idari birimlere örnek olarak verilebilir. Örneğin Zeytinburnu İstanbul'un ilk gecekondu alanlarındandır. Romanda gecekondulaşmanın oluşumu Zeytinburnu ve Beştelsizler üzerinden anlatılmaktadır. Bir başka örnek olarak Haydarpaşa Garı verilebilir. Haydarpaşa vurgusu yazarın anlatımında gurbet kavramıyla sıkı sıkıya bağlantılıdır. Romanda Haydarpaşa Garı köyden şehre gelmiş insanların duygusal durumunu yansıtan bir mekân olarak karşımıza çıkmaktadır. Her ne kadar romanda geçmese de Orhan Kemal'in İkbal Kahvesi tüm bu kurguya ilham kaynağ ${ }_{1}$ olan, döneminin önemli edebiyatçılarının bir araya geldiği toplanma alanı olma özelliği taşımaktadır. Ayrıca Gurbet Kuşları romanında semtlerin aktarımı da oldukça belirgindir. Orhan Kemal gözlemlediği ve tanık olduğu olayların geçtiği İstanbul'un Ortaköy, Unkapanı, Nişantaş1, Küçükpazar, Sirkeci, Eminönü, Karaköy gibi semtlerini de okuyucuya anlatmaktadır (Şekil 7).

\section{SONUC VE ÖNERÍLER}

Günümüzde Coğrafya'nın özellikle beşeri kolunun inceleme alanına girecek birçok alt araştırma alanı ortaya çıkmaktadır. Edebiyat Coğrafyası çıkış noktası olarak her ne kadar 1910'lu y1llara kadar geriye götürülecek bir geçmişe sahipse de, 1980'lerden sonra üzerinde yoğunlaşılan bir araştırma alanı olmuştur. Ülkemiz özelinde ise Edebiyat Coğrafyası çalışmaları çok daha yakın döneme tarihlenmektedir. Edebi eserlerdeki fiziki ve beşeri coğrafi unsurların tahlili ve bunların gösterilmesi, bu eserlerin coğrafi bir merkezle okunması Coğrafya biliminin toplumsal alanda yaygınlaşmasına önemli katkılar sunmaktadır. Normal koşullarda ağırlıkla akademik alanla sınırlı kalan Coğrafya çalışmaları, özellikle roman gibi edebi türlerle çok daha geniş bir kitleye ulaşabilecektir. Dolayısıyla edebi eserlere dair yapılacak coğrafi analizler ileride yazarları eserlerinde coğrafi unsurları daha fazla kullanmaya teşvik etme potansiyeline sahiptir.

Orhan Kemal, Türkiye'nin 1950 sonrası gelişen şehirleşmesanayileşme ilişkisini bire bir gözlemlemiş ve bu gözlemlerini eserlerine toplumcu gerçekçi perspektif üzerinden aktarmıș bir yazardır. Eserlerinin birçoğunda şehirle yakından bağlantılı beşeri coğrafi unsurların kullanımı dikkat çeker. Bu çalışmada da yazarın "Bereketli Topraklar Üzerinde" ve "Gurbet Kuşları" romanlarının belirlenen şehirsel coğrafi unsurlar kapsamında oluşturulmuş kodlamalarla analizi yapılmıştır. Yazarın insanla olan yakın teması romanlarındaki beşeri coğrafi unsurların ve bunların mekânsal yansımalarının ağırlıkta olmasını sağlamıştır. Bu açıdan yazarın eserlerinde fiziki coğrafi unsurların anlatımının az olması belirgindir. Buna karșılık ulaşım, sanayi, konut, ticaret gibi şehirsel fonksiyonların satır aralarında verilişi, gecekondulaşma, 1950'lerin İstanbul'undaki imar hareketleri, şehirsel coğrafi görünümler yazarın anlatımındaki belirgin beșeri coğrafi unsurları oluşturmaktadır. Ayrıca bu çalışmaya konu olan eserlerdeki yer ve mekânların kullanımı yerleşmelerin evrimsel sürecine de tanıklık etmesi bakımından önemlidir.

Günümüzde Coğrafya'nın multidisipliner olma vasfı gittikçe kuvvetlenmektedir. Gelişen ve değişen dünyada Coğrafya'nın 
pratik karşıllıklarının güçlendirilmesinin bir yolu da multidisipliner alanlarla olan bağının güçlendirilmesinden geçmektedir. Bu çalışma Edebiyat-Coğrafya ilişkisine yaklaşım açısından yöntemsel ve konusal açıdan özgünlükler barındırmaktadır. Dünya ve Türk edebiyatında kasıtlı olarak veya olmayarak coğrafi unsurların kullanımı oldukça fazladır. $\mathrm{Bu}$ açıdan coğrafyacıların önünde zengin bir kaynak bulunmaktadır. Gelecekte bu alanda yapılacak birçok çalışma Coğrafya biliminin diğer bilimlerle bağını kuvvetlendireceği gibi, bilimler arasındaki öneminin de daha fazla artmasını sağlayacaktır.

Hakem Değerlendirmesi: Dış bağımsız.

Çıkar Çatışması: Yazarlar çıkar çatışması bildirmemiştir.

Finansal Destek: Yazarlar bu çalışma için finansal destek almadığını beyan etmiştir.

Peer-review: Externally peer-reviewed.

Conflict of Interest: The authors have no conflict of interest to declare.

Grand Support: The authors declared that this study has received no financial support.

\section{KAYNAKÇA/REFERENCES}

Alver, K. (2009, Haziran). Kent ve kültür üzerine notlar. Hece Dergisi, 150-151-152, 428-433.

Aseguinolaza, F. (2003). Geography and literature: on a comparative history of the literatures in the Iberian Peninsula. Neohelicon, 30(1), 117-125. http://dx.doi.org/ 10.1023/A:1024118608824

Avcı, S. (2000). Türkiye'nin ekonomi politikaları ve coğrafi sonuçları. Coğrafya Dergisi, (8), 29-70. Erişim adresi: https://dergipark.org.tr/ tr/pub/iucografya

Avc1, S. (2005). Two papers about urbanization in Turkey. Istanbul: Çantay Yayınevi.

Brosseau, M. (1994). Geography's literature. Progress in Human Geography, 18(3), 333-353. https://doi.org/10.1177/03091325940 1800304

Cobutoğlu, S. (2014). Ahmed Mithat Efendi'nin romanlarında edebiyat coğrafyası: Karadeniz ve çevresi. (Doktora Tezi). Marmara Üniversitesi Türkiyat Araştırmaları Enstitüsü, İstanbul.

Darby, H. (1948). The regional geography of Thomas Hardy's Wessex. Geographical Review, 38(3), 426-443. http://dx.doi.org/ 10.2307/ 210904

Darkot, B. (1956). Altıncı genel nüfus sayımı. Türk Coğrafya Dergisi, (15-16), 85-103. Erişim adresi: https://dergipark.org.tr/ pub/tcd

Darkot, B. (1961). Türkiye'nin nüfus hareketleri üzerinde yeni gözlemler. Türk Coğrafya Dergisi, (21), 1-14. Erişim adresi: https:// dergipark.org.tr/ pub/tcd

Doğanay, H. (1999). Coğrafya 'ya giriş (5.bs). Konya: Çizgi Kitabevi.

Emiroğlu, M. (1963). Zonguldak ve Batı Karadeniz bölümünde nüfus hareketleri. Türk Coğrafya Dergisi, (22-23), 149-168. Erişim adresi: https://dergipark.org.tr/ pub/tcd
Gültekin, M. (2011). Orhan Kemal'in romanlarında modernleşme, birey ve gündelik hayat (2.bs). İstanbul: Everest Yayınlar1.

Herendeen, W. (1986). From landscape to literature: the river and the myth of geography. Pittsburgh: Duquesne University Press.

Hones, S. (2010). Teaching and learning guide for: text as it happensliterary geography. Geography Compass, 4(1), 61-66. http://dx.doi. org/ 10.1111/j.1749-8198.2009.00291.x

Hones, S. (2015). Literary geographies, past and future. Literary Geographies, 1(2), 1-5. Erişim adresi: https://www.literarygeographies.net/

İnandık, H. (1956). Adapazarı Ovası ve çevresinde nüfus ve yerleşme. Istanbul Üniversitesi Coğrafya Enstitüsü Dergisi, 4(7), 66-91.

Kaçmaz, M., \& Kaçmaz, P. (2019). Edebiyat coğrafyası; Elif Şafak romanlarının coğrafi terim ve mekân analizleri. Türk Coğrafya Dergisi, 73, 53-60. http://dx.doi.org/ 10.17211/tcd.585678

Kaçmaz, P. (2017). Edebi metinlerde coğrafi perspektif; Elif Şafak romanlarının analizi. (Yüksek Lisans Tezi). Sakarya Üniversitesi Sosyal Bilimler Enstitüsü, Sakarya

Kaplan, M. (1978). Nesillerin ruhu (4.bs). İstanbul: Dergâh Yayınları.

Kefeli, E. (2009). Coğrafya merkezli okuma. Turkish Studies, 4(1), 423433. http://dx.doi.org/10.7827/TurkishStudies.552

Kemal, O. (2012). Yaşam ve sanat serüvenim. A. Ümit, \& I. Öğütçü (Ed.), Orhan Kemal kitabı içinde (s. 11-20). Ankara: T.C. Kültür ve Turizm Bakanlığı.

Kemal, O. (2018a). Bereketli topraklar üzerinde (43.bs). İstanbul: Everest Yayınları.

Kemal, O. (2018b). Gurbet kuşları (13.bs). İstanbul: Everest Yayınları.

Korkut, C. (1974). İzmir şehrinin coğrafi özellikleri. Türk Coğrafya Dergisi, (26), 87-105. Erişim adresi: https://dergipark.org.tr/ pub/tcd

Mill, H. (1910). Guide to geographical books and appliances. Sydney: Wentworth Press.

Muehrcke, P., \& Muehrcke, J. (1974). Maps in literature. Geographical Review, 64(3), 317-338. Erişim adresi: https://www.jstor.org/

Narlı , M. (2012). Orhan Kemal ve mekân. A. Ümit, \& I. Oğutçu (Ed.), Orhan Kemal kitabı içinde (s. 104-117). Ankara: T.C. Kültür ve Turizm Bakanlığı.

Öngör, S. (1958). Türkiye'de dahili muhaceret hakkında. Türk Coğrafya Dergisi, (18-19), 101-117. Erişim adresi: https://dergipark.org.tr/ pub/tcd

Öngör, S. (1961). 1950-1955 devresinde Türkiye'de iç göçler. Türk Coğrafya Dergisi, (21), 63-74. Erişim adresi: https://dergipark.org. tr/ pub/tcd

Özçağlar, A. (2010). Coğrafyaya giriş sistematik, kavramlar, yöntemler. Ankara : Ümit Ofset Matbaac1lık.

Peraldo, E. (2016). Literature and geography: the writing of space throughout history. Newcasatle: Cambridge Scholars Publishing.

Piatti, B., Reuschel, A.-K., \& Hurni, L. (2009, Kasim). Literary geography - or how cartographers open up a new dimension for literary studies. 24th International Cartographic Conference, Santiago, Şili

Pocock, D. (1981). Place and the novelist. Transactions of the Institute of British Geographers, 6(3),337-347.http://dx.doi.org/10.2307/622292

Pocock, D. (2014). Humanistic geography and literatüre. London and New York: Routledge. 
Porteous, J. (1985). Literature and humanist geography. The Royal Geographical Society, 17(2), 117-122. Erişim adresi: https://www. jstor.org/

Salter, C., \& Lloyd, W. (1977). Landscape in literature. Resource Papers For College Geography No. 76-3. Washington: Association of American Geographers.

Selen, H.S. (1945). Türkiye'de köy yerleşmeleri ve şehirleşme hareketleri. Türk Coğrafya Dergisi, (7-8), 97-106. Erişim adresi: https://dergipark.org.tr/ pub/tcd

Sergün, Ü. (1974-1977). Türkiye'de nüfus artışı ve sorunları. Ístanbul Üniversitesi Coğrafya Enstitüsü Dergisi, (20-21), 211-222.

Sharp, J. (2000). Towards a critical analysis of fictive geographies. Area, 32(3), 327-334. Erişim adresi: https://www.jstor.org

Silk, J. (1984). Beyond geography and literature. Environment and Planning D: Society and Space, 2(2), 151-171. http://dx.doi. org/10.1068/d020151

Strauss, A., \& Corbin, J. (1990). Basics of qualitative research: grounded theory procedures and techniques. Newbury Park, CA: Sage.

Sözer, N. (1967). Erzurum'da şehirleşme hareketleri ve gecekondu problemi. Türk Coğrafya Dergisi, (24-25), 194-213. Erişim adresi: https://dergipark.org.tr/ pub/tcd

Şen, E. (1974). Ankara şehri mesken alanlarının gelişimi gecekondu sorunu açısından. Türk Coğrafya Dergisi, (26), 73-86. Erişim adresi: https://dergipark.org.tr/ pub/tcd

Thacker, A. (2005). The idea of a critical literary geography. New Formations, (57), 56-73. Erişim adresi: https://www.lwbooks.co.uk

Thrift, N. (1978). Landscape and literature-letters to the editor. Environment and Planning, 10(3), 347-349. http://dx.doi.org/ 10.1068/a100345

Tuan, Y.-F. (1976). Literature, expererience, and environmental knowing. In G. Moore, \& R. Golledge (Eds.), Environmental knowing: theories, research and methods (s. 260-272). Stroudsburg, Pennsylvania: Dowden, Hutchinson \& Ross.
Tuan, Y.-F. (1990). Topophilia a study of environmental perception, attitudes, and values. New York: Colombia University Press.

Tuncel, M. (1973). İzmit şehri ve yayılış sahası. İstanbul Üniversitesi Coğrafya Enstitüsü Dergisi, (18-19), 167-188.

Tunçdilek, N. (1957). Eskişehir ve şehrin tekâmülü. İstanbul Üniversitesi Coğrafya Enstitüsü Dergisi, 4(8), 35-47.

Tümertekin, E., \& Tunçdilek, N. (1961). 1960'da Türkiye nüfusu. Ístanbul Üniversitesi Coğrafya Enstitüsü Dergisi, 6(22), 78-89.

Tümertekin, E. (1965). Türkiye'deşehirlerinfonksiyonel sınıflandırılması. İstanbul: İstanbul Üniversitesi Coğrafya Enstitüsü Yayınları.

Tümertekin, E. (1977). Türkiye'de iç göçler üzerine. İstanbul Üniversitesi Coğrafya Enstitüsü Dergisi, (22), 29-42.

Tümertekin, E., \& Özgüç, N. (2002). Beşeri coğrafya insan, kültür, mekân. İstanbul: Çantay Yayınları.

Uyar, F. (2015). Orhan Kemal'in Bereketli Topraklar Üzerinde romanında kentte yiten insan. Mavi Atlas, (5), 43-52. http://dx.doi. org/10.18795/ma.50811

Wright, J. (1924). Geographical record-geography in literature. Geographical Review, 14(4), 659-660. Erişim adresi: https://www.jstor.org/

Wright, J., \& Platt, E. (1947). Aids to geographical research: bibliographies, periodicals, atlases, gazetteers, and other reference books. New York: American Geographical Society.

Yıldırım, A., \& Şimşek, H. (2016). Sosyal bilimlerde nitel araştırma yöntemleri. Ankara: Seçkin Yayıncılık.

Y1lmaz, B. (2007). Elif Şafak’ın romanlarında mekân ögesinin zamankişi ve olay bağlamında incelenmesi. (Yüksek Lisans Tezi). Eskişehir Osmangazi Üniversitesi, Sosyal Bilimler Enstitüsü, Eskişehir.

Yücel, T. (1960). Türkiye'de şehirleşme hareketleri ve şehirler (birinci makale). Türk Coğrafya Dergisi, (20), 23-35. Erişim adresi: https:// dergipark.org.tr/ pub/tcd

Yücel, T. (1961). Türkiye'de şehirleşme hareketleri (ikinci makale). Türk Coğrafya Dergisi, (21), 31-44. Erişim adresi: https://dergipark. org.tr/ pub/tcd 